Florida State University College of Law

Scholarship Repository

Scholarly Publications

1992

\title{
A Civic Republican Justification for the Bureaucratic State
}

Mark Seidenfeld

Follow this and additional works at: https://ir.law.fsu.edu/articles

Part of the Administrative Law Commons

\section{Recommended Citation}

Mark Seidenfeld, A Civic Republican Justification for the Bureaucratic State, 105 HARV. L. REV. 1511 (1992),

Available at: https://ir.law.fsu.edu/articles/3

This Article is brought to you for free and open access by Scholarship Repository. It has been accepted for inclusion in Scholarly Publications by an authorized administrator of Scholarship Repository. For more information, please contact efarrell@law.fsu.edu. 


\title{
A CIVIC REPUBLICAN JUSTIFICATION FOR THE BUREAUCRATIC STATE
}

\author{
Mark Seidenfeld
}

\section{TABLE OF CONTENTS}

PAGE

I. The Shaky Constitutional Foundation of the Administrative State $\ldots$ is 6

II. Civic Republicanism - Its Promises and Its Pitfalls $\ldots \ldots \ldots \ldots \ldots \ldots \ldots \ldots$

A. Civic Republicanism Defined .............................. 1528

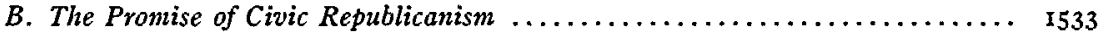

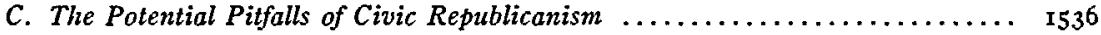

III. The Administrative State as a Means of Fulfilling the Civic

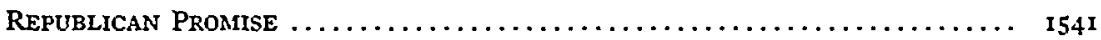

A. The Place of Administrative Agencies in American Government .......... 1543

1. Availability of Judicial Review to Ensure Deliberative Decisionmaking .... 1543

2. Availability of Review by Politically Accountable Branches ........... 1550

B. The Structure of the Bureaucracy ........................... 1554

1. The Prafessional Rather than Political Nature of the Staff .......... 1555

2. The Pyramidal Structure of Agencies ....................... 1559

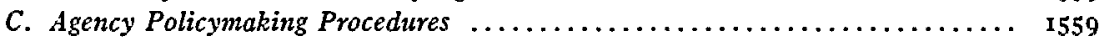

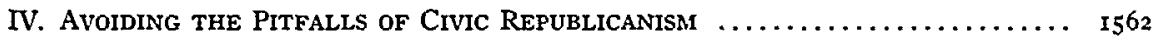

A. Regulation that Promotes Decisionmakers' Private Interests ............ 1563

B. Agency Capture by Private Interest Groups ...................... 1565

C. Regulators' Pursuit of Their Own Conception of the Public Interest ......... 1570

D. Coercion by the Dominant Political Culture $\ldots \ldots \ldots \ldots \ldots \ldots \ldots \ldots \ldots \ldots \ldots \ldots \ldots$

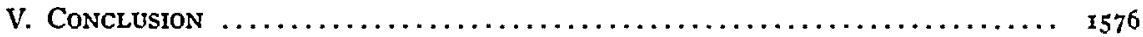




\title{
A CIVIC REPUBLICAN JUSTIFICATION FOR THE BUREAUCRATIC STATE
}

\author{
Mark Seidenfeld
}

Scholars have debated the legitimacy of the modern administrative state since its rise in the early twentieth century. In this Article, Professor Seidenfeld argues that the political theory of civic republicanism, with its emphasis on citizen participation in government and deliberative decisionmaking, provides the best justification for the American bureaucracy. Beginning with an analysis of civic republican theory, he notes that it promises greater citizen involvement in political decisionmaking, yet at the same time threatens to increase government power. Professor Seidenfeld finds that the current regime of administrative law neither allows for the full realization of civic republicanism's potential nor guards adequately against its dangers. He therefore suggests political and legal reforms applicable to the three constitutional branches of government and the bureaucracy itself.

$\mathrm{O}$

VER the past century, the powers and responsibilities of administrative agencies have grown to an extent that calls into question the constitutional legitimacy of the modern federal bureaucracy. Congress frequently authorizes agencies to adopt rules to implement broadly worded statutory provisions. ${ }^{1}$ Courts defer to agencies' applications of legal standards in particular situations ${ }^{2}$ and now even defer to agencies' abstract interpretations of statutory provisions. ${ }^{3}$ The President is often unable to mandate that agencies adopt her policies. ${ }^{4}$

* Visiting Professor, William Mitchell College of Law; Assistant Professor, Florida State College of Law. I owe thanks to numerous colleagues who read and commented on earlier drafts, but I would like to express special appreciation to Rob Atkinson for his encouragement and numerous insights. I would also like to thank Lisa Kuhlman and Karin Carlson for their dedicated research assistance.

${ }^{1}$ See, e.g., Federal Trade Commission Act, 15 U.S.C. $\$ 45(a)(2)$ (1988) (requiring the FTC to "prevent persons . . . from using unfair methods of competition"); Federal Power Act, I6 U.S.C. $\$ 824$ e(a) (I988) (requiring the FERC to set electricity transmission wholesale electric rates that are "just and reasonable" and not "unduly discriminatory"); Federal Communication Act, 47 U.S.C. $\$ 303$ (I988) (requiring the FCC to regulate broadcasting "as the public convenience, interest or necessity requires"); see also Peter L. Strauss, Legislative Theory and the Rule of Law: Some Comments on Rubin, 89 CoLUM. L. REV. 427, 427-30 (I989) (describing the shift from congressional standard-setting to congressional delegation to agencies, which then set the standards themselves).

2 See, e.g., Skidmore v. Swift \& Co., 323 U.S. 134, 139-40 (1944).

${ }^{3}$ See, e.g., Chevron U.S.A., Inc. v. Natural Resources Defense Council, Inc., 467 U.S. 837 , 843-45 (1984); Ford Motor Credit Co. v. Milhollin, 444 U.S. 555, 565-69 (rg8o).

${ }^{4}$ Legislation passed by Congress defines and limits agency power to act, and the agency must regulate in accordance with its enabling statute. The President cannot legally make a decision that Congress has entrusted to an agency; she can only try to persuade the agency to decide as she would like. See Morrison v. Olson, 487 U.S. 654, 69I-96 (x988). The President 
In short, in the modern state, many agency decisions involve political choices that "make law," even though agencies exist outside traditional conceptions of our tripartite national government.

The political nature of agency decisions has sparked controversy about the extent to which American constitutional democracy should permit unelected administrators to define fundamental regulatory policies. ${ }^{5}$ Supporters of the bureaucratic state have at different times offered three distinct justifications for administrative lawmaking. Before the New Deal, commentators claimed that agency authority to issue rules in narrow regulatory areas was necessary to fulfill explicit congressional policy. ${ }^{6}$ The New Deal, however, granted agencies policymaking authority that clearly exceeded the bounds justified by necessity. New Dealers, forced to find an alternative justification, asserted that agency decisions were applications of technical expertise, best made outside an environment influenced by interest groups and the political process. ${ }^{7}$ This justification, however, ignored the reality that most agency decisions did not follow from uncontroversial expert evaluation, but rather hinged on outside influence and the political leanings of agency members. The realization that agencies act politically spawned a third justification for the administrative state that drew upon the political theory of pluralistic democracy, which likens political processes to markets. ${ }^{8}$ Delegation of political decisions to

has no direct authority over "independent agencies"; she can neither dictate her policies to them nor remove agency members, except for statutorily defined cause, and removal is reviewable by the courts. See Humphrey's Executor v. United States, 295 U.S. 602, 629-30 (1935). The President does have the authority to remove the heads of "executive agencies" at will but pragmatically this still does not give her the power to dictate agency policy. A President might face great political pressure if she removed an agency head for adopting a policy with which the President disagreed after the agency had developed a record and carefully explained how that policy furthered the enabling statute's goals. Cf. Martin Shapiro, Who Guards the GuARDIANS? II 2 (Ig88) (noting that the participants in a rulemaking proceeding would be "outraged" if at the end the President simply told the agency which rule to adopt). Furthermore, the President might not want to replace the agency head if she otherwise considers the agency head to be effective. Finally, replacing the agency head will only have an effect if the President can be sure that she can get the Senate to approve the appointment of a replacement who will heed the President's command. See generally Peter L. Strauss, The Place of Agencies in Government: Separation of Powers and the Fourth Branch, 84 CoLUM. L. REv. 573, 587-91 (Ig84) (discussing presidential direction of agencies).

s See, e.g., Theodore J. Lowi, The ENd of Liberalism 92-I 26 (2d ed. I979); James 0. Freedman, Delegation of Power and Institutional Competence, 43 U. CHI. L. REv. 307, 307309 (1976); Gerald E. Frug, The Ideology of Bureaucracy in American Law, 97 HARV. L. REv. 1276 , $1279-80$ (1984).

${ }^{6}$ See Frank J. Goodnow, The Principles of the Administrative LaW of the United States 325-26 (1905); A. A. Berle, Jr., The Expansion of American Administrative Law, 30 HARV. L. REv. $430,44^{\mathrm{I}-42}$ (I9I7).

7 See James M. Landis, The Administrative Process i42-43 (1938).

8 See James M. Buchanan \& Gordon Tullock, The Calculus of Consent: Logical Foundations of Constitutional Democracy 288-89 (ig65). 
agencies was defended as a means of reaching the efficient regulatory equilibrium. ${ }^{9}$

All of these defenses of agency policymaking explain and justify some existing congressional delegations of lawmaking functions to agencies and judicial deference to agency decisions. None of the arguments, however, account for delegations that are prompted by neither a need for technical expertise nor a desire for agency dealmaking to resolve regulatory issues.

Recently, commentators have proffered an alternative understanding of the constitutional constraints on government regulation - the "civic republican" theory of constitutional democracy. 10 Modern civic republicans view the Constitution as an attempt to ensure that government decisions are a product of deliberation that respects and reflects the values of all members of society. Civic republicanism promises democratic government that does not exclude or coerce citizens whose backgrounds and values differ from those of mainstream society. ${ }^{11}$ The civic republican model rejects the pluralistic assertion that government can, at best, implement deals that divide political spoils according to the pre-political preferences of interest groups. Instead, government's primary responsibility is to enable the citizenry to deliberate about altering preferences and to reach consensus on the common good. ${ }^{12}$

One prominent proponent of civic republicanism, Cass Sunstein, has noted that it tolerates regulation by an extensive bureaucracy more than does pluralist theory. ${ }^{13}$ Yet Sunstein adheres to the traditional

${ }^{9}$ For the historical development of these justifications and models for administrative decisionmaking, see SHAPIRO, supra note 4, at 36-54; and Richard B. Stewart, The Reformation of American Administrative Law, 88 HARV. L. REV. I667, I67I-88 (1975).

${ }^{10}$ See, e.g., Michael J. Perry, Morality, Politics, and the Law Io2-03 (I988); Bruce A. Ackerman, The Storrs Lecture: Discovering The Constitution, 93 YALE L.J. 1013, 1032-43 (1984); Frank I. Michelman, The Supreme Court, 1985 Term - Foreword: Traces of SelfGovernment, Ioo HARv. L. Rev. 4, I7-77 (1986); Cass R. Sunstein, Interest Groups in American Public Laze, 38 Stan. L. Rev. 29, 45-48 (1985). See generally Symposium, The Republican Civic Tradition, 97 YALE L.J. 1493 (1988) (detailing most aspects of civic republican theory). This revival is part of a more general rekindling of interest in republicanism in constitutional history, see, e.g., David F. Epstein, The Political Theory of The Federalist 4-7 (1984); J.G.A. Pocock, The Machiavellian Moment 506-52 (1975); Robert E. Shalhope, Toward a Republican Synthesis: The Emergence of an Understanding of Republicanism in American Historiography, 29 WM. \& MARY Q. 49, 49 (I972), and philosophical justifications for the state, see, e.g., Michael J. SANDEL, Liberalism aND THE Limits of Justice 17 I-83 (I982); Drucilla Cornell, Tozvard a Modem/Postmodern Reconstruction of Ethics, 133 U. PA. L. REV. 29I, 35980 (1985); Amy Gutmann, Communitarian Critics of Liberalism, I4 PHIL. \& PUB. AFF. 308, 320-22 (I985).

11 See Frank Michelman, Laz's Republic, 97 YALE L.J. 1493, I5I3 (1988).

12 See id. at 1526-28; Cass R. Sunstein, Beyond the Republican Revival, 97 Yale L.J. I539, 1548-49 (1988).

13 See, e.g., Cass R. Sunstein, After the Rights Revolution ro7-1o (1990); Sunstein, supra note 10, at 59-64; cf. Robert B. Reich, Public Administration and Public Deliberation: 
principle that "basic value judgments should be made by Congress."14 Sunstein thus seems to accept the bureaucracy as an unavoidable aspect of modern government and has set about the task of constraining administrative policy-setting discretion to fit within civic republicanism to the extent possible. ${ }^{15}$

By contrast, I believe that civic republicanism provides a strong justification for the assignment of broad policymaking discretion to administrative agencies. I agree with Sunstein that "[t]he exact amount of desirable agency discretion . . . will depend on the context."16 But I contend that, on the whole, civic republicanism is consistent with broad delegations of political decisionmaking authority to officials with greater expertise and fewer immediate political pressures than directly elected officials or legislators. Moreover, given the current ethic that approves of the private pursuit of self-interest as a means of making social policy, reliance on a more politically isolated administrative state may be necessary to implement something approaching the civic republican ideal.

I do not mean to imply that the politically accountable institutions - Congress and the President - play no role in my civic republican conception of the administrative state. They, as well as the judiciary, however, are not geared to implement the civic republican ideal directly. Instead, the three branches play a crucial role in my conception by reviewing agency policy to ensure that the bureaucracy does not fail to fulfill its civic republican promise.

In sum, I view the civic republican conception as providing an essential justification for the modern bureaucratic state. ${ }^{17}$ This Article argues that although the Congress, the President, and the courts retain an important reviewing function, having administrative agencies set government policy provides the best hope of implementing civic republicanism's call for deliberative decisionmaking informed by the values of the entire polity. ${ }^{18}$

An Interpretive Essay, 94 YALE L.J. I6I7, I631-4I (1985) (noting the potential of administrative agencies to foster public deliberation about policy decisions).

14 Cass R. Sunstein, Changing Conceptions of Administration, 1987 B.Y.U. L. Rev. 927, $94 \mathrm{I}$.

15 See, e.g., Cass R. Sunstein, Factions, Self-Interest, and the APA: Four Lessons Since 1946, 72 VA. L. REV. 271, 28I-92 (1986); Sunstein, supra note to, at 74-75.

${ }^{16}$ Cass R. Sunstein, supra note 14 , at 941 .

17 This does not mean that civic republicanism justifies the administrative state as it presently operates. I agree with Sunstein that many of the doctrines governil.g administrative decisionmaking reflect a pluralistic understanding of democracy and therefore should be modified. See, e.g., SunsteIn, supra note 13, at 107-10; Cass R. Sunstein, Interpreting Statutes in the Regulatory State, I03 HARv. L. REv. 405, 503-04 ( $\mathrm{g} 98 \mathrm{~g})$. I do not agree, however, with his principle that statutes should be interpreted to narrow agency discretion to set policy. See id. at $47^{\circ}$.

${ }_{18}$ Christopher Edley has reached somewhat similar conclusions about the role of agencies, courts, and Congress. See Christopher F. Edley, Jr., Administrative law: Rethinking 
This thesis has several implications for public policy. First, it suggests that congressional and judicial efforts to limit agency discretion and thereby eliminate perceived problems with the legitimacy of agency policymaking are often misguided. Second, if administrative policy-setting is to achieve the civic republican ideal, agency decisionmaking processes must proceed in a manner consistent with civic republican theory. Hence, my thesis suggests the need for numerous changes in administrative law. For example, Congress should amend the Administrative Procedure Act ${ }^{19}$ to require public involvement in the early stages of agency policy formulation. Congress should also require that its members and the White House staff reveal all of their interactions with agency personnel. Courts should abandon the rigid dichotomy that they draw between agency decisions of law and decisions of policy, and should review both for persuasiveness in light of pragmatic limitations.

The Article begins by reviewing the failure of traditional political theory to justify the broad grants of policy-setting authority that characterize the present administrative state. It proceeds to review civic republican theory and to make explicit both its promises and pitfalls. It then illustrates how broad grants of administrative discretion can provide a means of fulfilling the promises of civic republicanism. Finally, the Article evaluates the potential for policymaking by an administrative state to stumble into the theory's pitfalls.

\section{The Shaky Constitutional Foundation of THE ADMINISTRATIVE STATE}

The most traditional, and historically the first, justification for administrative policymaking authority asserts that the federal bureaucracy is necessary to implement Congress's political decisions, which are embodied in the statutes Congress passes. Under this "transmission belt" conception, agencies merely carry out Congress's statutory plan and do not themselves exercise political judgment. ${ }^{20}$ Thus, agency actions must follow statutory directives that dictate the appropriate decision for any given factual context. The agency must use procedures that ensure an accurate assessment of the facts so that it does not misapply statutory policy. Judicial review guards against agency decisions that deviate from legislatively determined policy.

Judicial Control of Bureaucracy 22I-34 (1990); see also Christopher Edley, Jr., The Governance Crisis, Legal Theory, and Political Ideology, I99I Duke L.J. 561, 588-98 (discussing the relationship of his "sound governance" standard to a civic republican conception of the administrative state).

${ }^{19} 5$ U.S.C. $\$ \$ 551-559,70 \mathrm{I}-706$ (I988).

${ }^{20}$ See Stewart, supra note 9, at $1672-76$. 
Judicial affirmation of agency orders also alleviates concerns about their legitimacy, because the Constitution, which represents the social compact to which "the People" agreed, envisions binding judicial orders. 21

Under the transmission belt model, agencies exercise only the discretion necessary to implement Congress's statutory directives. ${ }^{22}$ This discretion is not a delegation of the legislative function, even if the agency engages in "quasi-legislative" activity, such as setting rates or prescribing rules to govern conduct in narrow, fact-specific situations, because this activity merely brings to fruition Congress's political choice rather than some competing conception of what is best.

The transmission belt conception is seriously flawed. Arguably, it recognizes that even when Congress provides a detailed statutory prescription, agencies must exercise some judgment in implementing and enforcing it. The notion, however, that an agency can exercise judgment in implementing statutes without influencing and reshaping the political balance struck by Congress is, in most instances, a fiction. For example, in the Occupational Safety and Health Act of $1970,{ }^{23}$ Congress laid down a clear policy that mandated that ambient levels of toxic substances in the workplace be kept at the lowest levels feasible. ${ }^{24}$ Even as moderated by the Supreme Court, ${ }^{25}$ the policy, when strictly enforced, often requires great expenditures to reduce health risks only marginally. ${ }^{26}$ To avoid these outcomes, the Occupational Safety and Health Administration (OSHA) has simply declined to initiate proceedings to set workplace standards for many toxic substances. ${ }^{27}$ Hence, despite the clarity and inflexibility of the congressional policy (or perhaps even because of it), the agency has used its enforcement discretion to alter sharply that policy.

The transition belt model is also incomplete. Viewing agency discretion as a means of implementing congressional policy justifies only limited congressional delegation. It does not legitimate congres-

21 See id. at $1674-76$.

22 The usual exposition of the transmission belt model gives the impression that agencies should exercise no discretion. See id. at 1675 . The model, however, clearly envisions that the agency will make some choices, see id. at 1676 , and hence will exercise some judgment. The key to the transmission belt model is that agency discretion is tied to assessing factual circumstances and not to making or construing law or policy.

2329 U.S.C. $\$ \$ 65 I-678$ ( 1988 ).

24 See 29 U.S.C. \$ 655(b)(5) (1988).

${ }^{25} \mathrm{See}$ Industrial Union Dep't, AFL-CIO v. American Petroleum Inst., 448 U.S. 607, 63940 (Ig8o) (plurality opinion).

${ }^{26}$ See SunsteIN, supra note ${ }^{13}$, at 86, 239-40; John Mendeloff, Regulatory Reform and OSHA Policy, 5 J. Pol'y ANalysis \& MGMr. 440, 44I-42 (Ig86) (noting that the average cost of preventing one cancer fatality runs from several million to twenty million dollars).

27 See John M. Mendeloff, The Dilemima of Toxic Substance Regulation 2 (ig88); SUNSTEIN, supra note 13 , at $91-92$. 
sional reliance on agency expertise to make fundamental policy decisions. Nor does it justify the assignment of politically charged decisions to agencies. In reality, however, Congress commonly fails to make hard political choices when it passes a regulatory statute, thus necessitating that the agency responsible for implementing the law do so. ${ }^{28}$ Requiring government to conform to the transmission belt model would lead to the invalidation of many of the regulatory programs on which society relies, ${ }^{29}$ and would likely lead to congressional inertia even in the many situations in which all agree that some regulatory change is better than the status quo. ${ }^{30}$

The second, New Deal-era justification of bureaucratic decisionmaking relies on the concept of agency expertise. ${ }^{31}$ It recognizes that agency decisions do alter and, to a great extent, even determine the values ultimately promoted by regulation, but it regards this state of affairs as salutary. 32 Successful solutions to regulatory problems require the application of knowledge and experience that only agencies involved in day-to-day regulation of an industry can acquire, ${ }^{33}$ as well as insulation from political and legal constraints that only get in the way of good government. ${ }^{34}$ Hence, the New Deal contemplated that Congress should identify an area in need of regulatory control and turn the expert agency loose to regulate. ${ }^{35}$ The statutory and judicial

${ }^{28}$ See John H. Ely, Democracy and Distrust 131-32 (I980); Lloyd N. Cutler \& David R. Johnson, Regulation and the Political Process, 84 YALE L.J. I395, I400 (1975).

${ }^{29}$ The transmission belt model of administration was the basis for the non-delegation doctrine, which the Supreme Court applied for a brief period in 1935 in a vain attempt to block the New Deal vision of the administrative state. See Richard B. Stewart, Beyond Delegation Doctrine, 36 AM. U. L. Rev. 323, 326 \& n.20 (1987). Stewart and Richard Pierce seem to agree that application of a recently proposed version of the doctrine would invalidate most existing federal regulatory statutes. See Richard J. Pierce, Jr., Political Accountability and Delegated Power: A Response to Professor Lowi, 36 AM. U. L. REv. 39I, $40 \mathrm{I}-02$ (I987); Stewart, supra, at 325.

30 See Guido Calabresi, A Common law for the Age of Statutes 46 -58 (1982).

31 See Marver H. Bernstein, Regulating Business by Independent Commission 5 I (I955); LANDIS, supra note 7, at 23-24; Daniel J. Gifford, The New Deal Regulatory Model: $A$ History of Criticisms and Refinements, 68 MiNN. L. REv. 299, 306-07 (1983).

32 See LANDIS, supra note 7 , at 70 (arguing that setting detailed standards is better done "in the comparative quiet of a conference room than ... amid the turmoil of a legislative chamber or committee room"). Supreme Court decisions during this period aptly express this attitude. See, e.g., Phelps Dodge Corp. v. NLRB, 313 U.S. 177, 194 (1941).

${ }^{33}$ See LANDIS, supra note 7 , at 23-24.

34 See James O. Freedman, Crisis and Legitimacy: The Administrative Process and AMERICAN GovERNMENT 59-60 (1978) (noting that political scientists had called for the independence of agencies prior to the New Deal); LANDIS, supra note 7, at I13-I4; SELEcted PAPERS AND ADdRESSES OF Joseph B. EASTMAN 1942-44, at 375 (G. Lloyd Wilson ed., r948); cf. BeRnstein, supra note $3 \mathrm{I}$, at $5 \mathrm{I}-5^{2}$ (chronicling the relationship of the Progressive call for administrative independence to the New Deal administrative state).

35 Under the New Deal model, the agency's enabling act might provide limits on the scope of agency discretion. See LANDIS, supra note 7 , at 52-60. But in many areas of regulation, the architects of the New Deal believed that the enabling act should merely authorize the agency 
checks so important to the transmission belt model gave way to a faith that the "professional spirit" of New Deal regulators would deter them from setting unwise or excessively intrusive policy. ${ }^{36}$

Under the New Deal model, any deviation of a regulatory scheme from Congress's original conception does not derogate Congress's political choices, but rather results from the agency's superior information and technical capabilities. Although an agency's discretionary decisions do alter the ends promoted by a statutory scheme, the expertise justification implicitly assumes that if only everyone had the same information and expertise possessed by the agency, everyone would agree that such alterations execute the "will of the people." In essence, agency alterations in statutory policy reflect only technical assessments made outside the pressure of politics and are therefore value-neutral. ${ }^{37}$ In this sense, agency discretion to alter policy does not conflict with the Constitution's assignment of lawmaking power to the legislature.

The establishment of the Federal Radio Commission and its successor, the Federal Communications Commission, exemplifies congressional reliance on agency expertise to set policy. ${ }^{38}$ Congress enacted a regulatory scheme under which the Commission would grant licenses to serve "the public convenience, interest or necessity." 39 The Commission, however, has unbridled discretion to delineate what the public interest requires. For example, it was the Commission and not Congress that chose to emphasize the policy of diversity and local control of programming that still dictates the structure of our broadcasting system. ${ }^{40}$

Despite occasional instances when Congress seems to view agency expertise as a value-neutral means of reaching regulatory policy decisions, the New Dealers' justification also fails to explain many delegations of discretion that have become common in the past century. Technical assessments help identify the set of possible choices the agency faces and often elucidate the implications of those choices.

to regulate some industry or area of the economy, and it was best for the statute merely to specify that the agency further the "public interest." See SHapiro, supra note 4 , at 38 .

${ }^{36}$ See LANDIS, supra note 7 , at 99.

37 See M.J.C. Vile, Constitutionalism and the Separation of Powers 277-80 (1967).

${ }^{38}$ See FCC v. Pottsville Broadcasting Co., 309 U.S. 134, 136-38 (1940).

${ }^{39}$ Radio Act of 1927 , ch. $169, \$ 4,44$ Stat. 1162 , $1163-64$. That standard was retained in 1934 when Congress passed the Federal Communications Act, which created the FCC, see Communications Act of 1934 , ch. $652, \$ 303,48$ Stat. $1064,1082-83$, and it is still in existence today, see 47 U.S.C. $\$ 303$ ( 1988 ).

40 Despite the absence of an explicit statutory prescription of diversity and local control, the FCC has made it clear by rule and by particular licensing decisions that these factors would often be determinative. See Policy Statement on Comparative Broadcast Hearings, I F.C.C.2d 393, 394 (1965); Marc A. Franklin \& David A. ANDERson, Mass Media LaW 762-63 (4th ed. I 990 ). 
When all is said and done, however, expertise rarely eliminates the need for the agency to choose among competing values - a choice that is the essence of political decisionmaking. ${ }^{41}$

The discretion accorded to the Federal Communications Commission with respect to broadcast regulation illustrates the problem of agencies making value choices. Armed with the mandate to issue licenses in the public interest, the FCC formulated the notion that licensees controlled a public trust. As trustees, broadcasters were required to air programs that fulfilled their social responsibilities. In particular, they had to comply with the FCC's "fairness doctrine" by providing a "reasonable opportunity for the discussion of conflicting views on issues of public importance." 42 Adoption of this requirement resulted from the FCC's balancing of broadcaster freedom from government control against the need for responsible use of the airwaves. ${ }^{43}$ The choice between the public trust approach and a more laissez-faire approach to programming was not a matter of agency expertise, but rather a value choice about the social role that the broadcasting system should play.

Not only do FCC policies present clear examples of agency decisions based on political choices rather than mere technical expertise, but the supposed independence of the Commission also does little to shield its decisionmaking processes from blatant political influence. For example, the Commission's initial (albeit short-lived) rules governing cable television were "based on a private agreement among cable operators, broadcasters, and a group of copyright owners," adopted after prodding by the Nixon White House. ${ }^{44}$ Political influence also seems to have reached even the "quasi-judicial" licensing proceedings: during the Eisenhower administration, no "Republican" newspaper lost a comparative hearing for a television license to a "Democratic" paper, and no important paper that had supported Eisenhower's opponent, Adlai Stevenson, succeeded in such a proceeding. 45 These examples illustrate that expertise does not enable an agency to escape the tugs of politics and the need to make value-laden decisions.

During the past three decades, some scholars have attempted to justify bureaucratic power by appealing to the political theory of

41 See Sunstein, supra note 15 , at 281 .

42 Red Lion Broadcasting Co. v. FCC, 395 U.S. 367, 380 (1969) (quoting the Act of Sept. 14, 1959, § 1,73 Stat. 557, 557 (amending 47 U.S.C. \$ 315(a))). After keeping the fairness doctrine in place for over thirty years, the FCC repealed it in 1987. See In re Syracuse Peace Council, 2 F.C.C.R. 5043, 5057-58 (I987).

43 See Erwin G. Krasnow, Lawrence D. Longley \& Herbert A. Terry, The Politics of Broadcast Regulation 20 (3d ed. ig82).

44 Id. at 25 .

45 See William B. Ray, FCC: The Ups and Downs of Radio-TV Regulation 45 (I990); Bernard Schwartz, The Professor and the Commissions I62-64 (I959). 
pluralistic democracy. ${ }^{46}$ This theory views the constitutional scheme as a means of ensuring that political decisions distribute the benefits of regulation according to the pre-existing values and preferences of the citizenry. ${ }^{47}$ The number and specificity of individual interests at play in the national political arena make it impossible for members of Congress to assess each constituent's preferences regarding particular legislative choices. Instead, organized interest groups, thought to reflect voter preferences, guide legislators' behavior. ${ }^{48}$ Members of Congress take the political power of interest groups, particularly their ability to deliver votes at election time, into account when making legislative decisions. ${ }^{49}$

Although interest groups distill individual preferences into a more manageable set of common interests, this distillation does not fully enable legislators to assess the desires of their constituents. The diversity of issues that interest groups would like the government to address and the susceptibility of their interests to rapidly changing circumstances tax a legislative process notorious for its inefficiency. Consequently, pluralists believe that regulators should react only to interest groups that find the status quo sufficiently intolerable to incur the costs of complaining, and regulators should change policy only as much as is needed to quell these complaints. ${ }^{50}$ This approach, how-

${ }^{46}$ See, e.g., Samuel Krislov \& David H. Rosenbloom, Representative Bureaucracy and the American Political System 24-25 (I98I); $c f$. Stephen Breyer, Regulation and ITS REFORM 35I-52 (1982) (offering interest group representation as a partial, but somewhat flawed, justification for the power of administrative agencies).

47 See Anthony Downs, An Economic Theory of Democracy 36-38 (1957); Shapiro, supra note 4 , at 5-6. Shapiro distinguishes this "public choice," or economic, conception of pluralism from a more general political science notion, which views competition among interest groups as the best means of approximating a "public interest" that could conceivably be distinct from an aggregation of pre-existing private interests. See SHAPIRo, supra note 4, at 5-7. For examples of the political science account of pluralistic democracy, see RoBERT A. DAHL, PLURAlist Democracy in the United States: Conflict and Consent 23-24 (I967); and David B. Truman, The Governmental Process 512-I6 (I95I). The economic version of the theory dominates the legal literature today. See, e.g., Frank H. Easterbrook, The Supreme Court, 1983 Term - Foreword: The Court and the Economic System, 98 HARV. L. REv. 4, 45-46 (1984); Daniel A. Farber \& Philip P. Frickey, The Jurisprudence of Public Choice, 65 TEx. L. REv. 873, 878-83 (1987); William M. Landes \& Richard A. Posner, The Independent Judiciary in an Interest-Group Perspective, I8 J.L. \& EcoN. 875, 877-79 (1975).

48 See William A. Kelso, American Democratic Theory 7 -1o (1978); Truman, suppa note 47 , at $56-57,6 \mathrm{I}-62$.

49 See DAHL, supra note 47 , at $130-3 \mathrm{~T}$.

${ }^{50}$ For a more complete description of the incremental mode of setting policy, see Colin S. Diver, Policymaking Paradigms in Administrative Law, 95 HARV. L. REv. 393, 40I-og (I98I); and Charles E. Lindblom, The Science of "Muddling Through", I9 PuB. ADMIN. REv. 79, 8485 (1959). The close relationship between pluralistic theories of regulatory legitimacy and the incremental approach to regulation is noted by Martin Shapiro. See SHAPIRo, supra note 4, at 32. Pluralistic theory, however, need not rely on the incremental approach; if interest group pressure for regulatory response entailed a significant minimum investment (as it might given the cost of procedures for enacting regulatory laws or rules), the political market could be driven 
ever, requires policymakers to maintain a day-to-day awareness of the regulatory environment, perpetually assess whether interest groups are satisfied, and constantly consider incremental changes in policy that might better satisfy all interest groups. Congress, which must address all controversies throughout society, cannot devote to any one regulatory scheme the level of attention that this approach requires. ${ }^{51}$

Both the size of Congress and constitutional checks and balances slow legislative action and virtually assure that Congress cannot keep pace with the often rapid changes in circumstances that help shape interest groups' immediate political wants. ${ }^{52}$ An interest group can register its wants more effectively with an agency authorized to regulate a focused set of issues related to the group's interests. ${ }^{53}$ An agency not bogged down by the requirement of strict separation of powers or the need for majority approval by two large bodies of elected legislators can act more quickly and efficiently than Congress. ${ }^{54}$

Collective choice theorists have identified another problem with reliance on legislative decisionmaking. They question the ability of a majority voting scheme to yield stable outcomes in situations involving realistic assumptions about voters' underlying preferences. ${ }^{55}$ Stability is guaranteed only if a small core of individuals controls the voting agenda. ${ }^{56}$ The recent weakening of both party control and the committee system in Congress has reduced the control over the legislative agenda previously exercised by a few powerful committee chairs. This weakened control makes it less likely that Congress can resolve the multitude of political controversies affecting powerful interest

far from a stable equilibrium before regulators reacted. If this occurred, once the regulators react, they might have to make a fairly significant change in policy to restore the political market to a new stable equilibrium.

51 See Louis L. Jaffe, Judicial Control of Administrative Action 25-26 (I965).

52 See I KenNeth C. Davis, AdMinistrative LaW TREaTise $\$ 3.3$, at 152 (2d ed. I978); Pierce, supra note 29, at 404-05; Stewart, supra note 29, at 33 r.

53 See L. Harmon Ziegler \& G. Wayne Peak, InTEREST Groups in AMerican Society I6I (I972). But cf. JOHN E. ChUBB, INTEREST Groups AND tHE BUREAUCRACY 37-4I (1983) (arguing that although most interest groups lobby Congress, only the best funded and most focused attempt to influence policy through participation in costly agency proceedings).

54 See Peter Woll, Introduction to Public Administration and Policy: Selected Essays I, 8-9, II-I 2 (Peter Woll ed., I966); Peter H. Aranson, Ernest Gellhorn \& Glen O. Robinson, A Theory of Legislative Delegation, 68 CORNELL L. REV. I, 56-58 (1982).

55 See Kenneth J. Arrow, Social Choice and Individual Values I-8 (I95 I); AMartya

K. Sen, Collective Choice and Social Welfare $38-40$ (1970).

56 In that case, the stable outcome may not reflect the preference of a majority of the voters. In some instances, agenda control may even be manipulated to systematically ensure particular nonmajoritarian outcomes. See Michael E. Levine \& Charles R. Plott, Agenda Influence and Its Implications, 63 VA. L. REV. 56I, 564, 588-89 (1977); Richard D. McKelvey, Intransivities in Multidimensional Voting Models and Some Implications for Agenda Control, $12 \mathrm{~J}$. EcoN. THEORY $472,480-81$ (1976). 
groups. ${ }^{57}$ For these reasons, pluralistic democracy might justify the bureaucratic state as a more effective means of assessing and fulfilling the political demands of interest groups.

An example of a regulatory statute that many believe to be a product of interest group power is the Clean Air Act. ${ }^{58}$ Environmentally concerned legislators built a coalition with legislators from eastern states that produce high sulfur coal to influence the 1977 amendments to the Act. ${ }^{59}$ The coalition managed to get Congress to adopt language that could be read to require the Administrator of the Environmental Protection Agency (EPA) to set an effluent standard for coal burning power plants that would require plants to install scrubbers, but would not encourage them to buy cleaner but more expensive western coal. 60 Because the statute's language was unclear, however, the EPA had to resolve the scrubber question as part of the process of setting the effluent standard. ${ }^{61}$ After much wrangling among the various divisions of the EPA staff, the Agency seemed to conclude that a standard that relied only on scrubbers rather than on burning cleaner coal was not worth the cost it would impose on the industry, and, in fact, might have perverse environmental effects. ${ }^{62}$ Despite this conclusion, the EPA adopted a standard that essentially mandated the scrubbing option, ${ }^{63}$ ostensibly because the Administrator believed that one of the purposes of the 1977 amendments was to promote the use of highsulphur eastern coal. 64 At the expense of electricity consumers, the EPA thereby accommodated the eastern coal interests that had formed the coalition that helped pass the 1977 amendments.

Like its predecessors, pluralistic democracy theory does not fully justify the open-ended grants of discretion that characterize the modern bureaucratic state. ${ }^{65}$ The ability to deliver votes is the currency

57 See Richard J. Pierce, Jr., The Role of the Judiciary in Implementing an Agency Theory of Govemment, 64 N.Y.U. L. REV. 1239, 1246-47 (1989).

${ }^{58} 42$ U.S.C. $\$ \$ 740 \mathrm{I}-7642$ (I988).

59 Clean Air Act Amendments of 1977 , Pub. L. No. 95-95, 91 Stat. 685 (codified at 42 U.S.C. $\$ \$ 740 \mathrm{I}-7642$ (1988)). For a description of the events surrounding adoption of the 1977 amendments, see Bruce A. Ackerman \& William T. Hassler, Beyond The New Deal: Coal and the Clean Air Act, 89 YALE L.J. I466, I492-1502 (1980).

60 See Clean Air Act Amendments of 1977 , Pub. L. No. 95-95, \$ I04(a), 91 Stat. 685, 689 (codified at 42 U.S.C. $\$ 7408$ (I 988 )).

61 See Ackerman \& Hassler, supra note 59, at I502-I I.

${ }^{62}$ See id. at $1547-50$.

${ }^{63}$ See id. at $1553-55$.

64 See id. at 1503 .

65 Moreover, the consistency of pluralistic democracy with our constitutional framework is highly debatable. Because of imperfections in the political market, there may be groups that command greater political resources than the resources they would have had if such resources were directly correlated with the number of people sharing the group's interest and the intensity with which people favor that interest. See SHAPIRo, supra note 4 , at 8-9. Moreover, pluralistic theory ignores the Federalists' concern with checking the influence of private factions that is 
of pluralistic democracy, but agency members are not directly elected. Pluralistic democracy must therefore rely on a politically accountable Congress and President to influence agency action and ensure that the agency implements the original political "bargain" that prompted the adoption of the authorizing legislation. Traditionally, Congress constrains agency decisionmaking by sufficiently specifying the parameters of the bargain in the enabling legislation and relies on non-deferential judicial review to guard against any unlawful action. But delegation of lawmaking authority to agencies under a broadly worded statute gives little direction to agencies or reviewing courts regarding the precise bounds of the legislative deal. In other words, when Congress enacts broad enabling legislation, it forfeits the traditional means of constraining agency action. Therefore, to justify the broad delegation of lawmaking authority that characterizes the modern administrative state, pluralistic democracy must find another mechanism to ensure agency fidelity to the statutory deal struck by special interest groups.

Congress and the President may choose from several mechanisms to try to keep agency decisions within the bounds of the original statutory deal. They may monitor agency decisions and give the agency feedback, either directly by meeting with agency members and participating in agency proceedings, or indirectly through budget allocations and statutory amendments. ${ }^{66}$ Alternatively, they may structure agency decisionmaking processes to give advantages to the interest groups that comprised the coalition responsible for the authorizing legislation. ${ }^{67}$ Both empirical and theoretical analyses, however, demonstrate that these mechanisms do not perform the job pluralistic theory requires of them.

Empirical studies cast doubt on pluralistic democracy's basic premise that legislators single-mindedly pursue reelection by appeasing special interest groups. Several scholars have concluded that serving organized interest groups is but one of many factors influencing how legislators vote. ${ }^{68}$ With respect to congressional interaction with agen-

reflected in the Constitution's system of a representative government with checks and balances. See Epstein, supra note ro, at $126-6 \mathrm{r}$.

${ }^{66}$ See Louis L. Jaffe, The Illusion of the Ideal Administration, 86 HARv. L. REv. 1183, IIgo-9I (I973); Strauss, supra note 4, at 586-95; Barry R. Weingast \& Mark J. Moran, Bureaucratic Discretion or Congressional Control? Regulatory Policymaking by the Federal Trade Commission, 9r J. POL. ECON. 765, 768-69 (I983).

${ }^{67}$ See generally Matthew D. McCubbins, Roger G. Noll \& Barry R. Weingast, Structure and Process, Politics and Policy: Administrative Arrangements and the Political Control of Agencies, 75 VA. L. REV. 43I, 432-35 (1989) (arguing that political control of bureaucratic agents is best accomplished by an ex ante implementation of administrative procedures rather than ex post legislation).

68 For a review of empirical studies that test the economic theory of legislation, see Farber \& Frickey, supra note 47 , at $895-98$ \& nn. $447-52$. Legislators also take into account the interests of their unorganized constituents, political affiliations, and personal beliefs about what best serves the public interest. See id. at goo \& n.165. 
cies, evidence suggests that legislators generally do not monitor agency decisions or attempt to gain electoral support by reacting to them through the statutory amendment or the budget process. Instead, legislators appear to garner the support of their constituents by acting as ombudsmen in agency matters concerning constituent interests. ${ }^{69}$ They thereby serve their constituents without having to take a public stance that may anger other supporters. When Congress as a body does react to agency decisions or policies, it does not always overrule those that harm well-organized interest groups. Instead, Congress usually strikes some new compromise that differs from the understanding that existed before the agency acted, and may even attempt to overrule or limit agency decisions that favor well-organized special interest groups. ${ }^{70}$ Thus, when Congress does attempt to "modify" agency action, it does not appear simply to reinstate a preset political deal struck by special interest groups.

Theoretical considerations reinforce the doubts raised by the empirical studies. If Congress does in fact monitor agency policy, it does so through the efforts of particular committee members. Agency policy would then depend on the interests of those legislators' constituents and supporting interest groups, ${ }^{71}$ which may not be the same as the groups that forged the coalition responsible for the initial legislative deal. To illustrate this point further, consider the possible congressional reactions to objectionable agency policy choices: direct participation in agency proceedings by legislators, budget reallocation, and substantive legislation. These mechanisms involve different internal legislative dynamics and the influence of different sets of legislators. It would be merely coincidental if the application of these processes all resulted in the same political deal that the enabling legislation originally struck.

Theoretical analysis also suggests that, once the agency acts, Congress and the President may not be able to reinstate the original deal regardless of the means of correction chosen. Once the agency acts contrary to the understanding of the original legislative deal, the agency alters the status quo. This alteration generally will change the willingness of some members of the majority coalition that enacted the original deal to reinstate the coalition's original understanding. ${ }^{72}$

69 See Pierce, supra note 57 , at 1245 .

70 Congress's refusal to benefit a well-funded and focused interest group is consistent with studies that have shown that political ideology is at least as important a factor in legislative voting as constituent and group interests. See, e.g., Robert A. Bernstein \& Stephen R. Horn, Explaining House Voting on Energy Policy: Ideology and the Conditional Effects of Party and District Economic Interests, 34 W. PoL. Q. 235, 245 (198I); Judith Goldstein, The Political Economy of Trade: Institutions of Protection, 80 AM. POL. SCI. REV. 161, 178-79 (1986).

71 See Weingast \& Moran, supra note 66, at $770-75$.

72 See McCubbins, Noll \& Weingast, supra note 67 , at $435-40$. 
Therefore, the greater the latitude given to the agency to make law consistent with only broad legislative prescriptions, the greater the likelihood that the regulatory scheme will alter the original legislative deal. Even if the coalition could agree to overrule the agency and implement the original deal, it would have to spend much time and effort monitoring the agency's decisions to ensure compliance - time and effort legislators might more profitably spend addressing particular constituent complaints and concerns regarding ongoing agency matters. ${ }^{73}$

Some commentators have suggested that the inability of Congress and the President to monitor and control agency policy-setting directly leads them to mandate agency procedures that ensure fidelity to the original substantive deal. These commentators contend that Congress designs procedures to enable coalition members to monitor agency action before it becomes effective and to bias agency decisionmaking toward preferring these members' interests. ${ }^{74}$ Thus, Congress does not need explicitly to monitor or to correct deviant agency decisions.

This argument unrealistically discounts the difficulty of creating procedural constraints to ensure that agencies implement the legislative deal. First, this use of procedure assumes that there is some legislative bargain to be implemented. ${ }^{75}$ In many instances, however, it is the inability of the members of the enacting coalition to strike any bargain that prompts the assignment of the policy decision to the agency in the first place. Even when Congress does strike a deal, procedures are unlikely to ensure that an agency will faithfully execute it. A deal involves a compromise among competing interests. Procedures, however, tend to give advantages to one group over another rather than to balance interests in order to reproduce the original compromise. ${ }^{76}$ Moreover, the groups that are most adept at using procedures to their advantage are not necessarily those that formed the legislative coalition. In addition, procedures often have unforeseen consequences. ${ }^{77}$ For example, procedures may give a relative advan-

73 See id. at 434; Mathew D. McCubbins \& Thomas Schwartz, Congressional Oversight Overlooked: Police Patrols Versus Fire Alarms, 28 AM. J. PoL. Scr. 165, I68 (I984).

${ }^{74}$ See Mathew D. McCubbins, Roger G. Noll \& Barry R. Weingast, Administrative Procedures as Instruments of Political Control, 3 J.L. ECON. \& ORG. 243, 273-74 (I987); McCubbins, Noll \& Weingast, supra note 67 , at $443-44$.

$75 \mathrm{See}$ Glen O. Robinson, Commentary on "Administrative Arrangements and the Political Control of Agencies": Political Uses of Structure and Process, 75 VA. L. REV. 483, 484-87 (r989).

${ }^{76} \mathrm{Cf}$. Easterbrook, supra note 47 , at 46 (noting that if legislation is a compromise between special interest groups, then enforcement that favors one interest will not remain faithful to the statute).

${ }^{77}$ See Robinson, supra note 75 , at 490 . The controversy over coal-burning power plant emissions illustrates how agency structure can work against the enacting coalition. Because the EPA is an executive agency, the Department of Energy (also an executive agency) had a 
tage to groups with more focused interests in regulation, but they also add costs to agency action. Hence, if the agency action would benefit focused interest groups, then added procedures would adversely affect them. ${ }^{78}$

Congress would thus take great risks if it tried to use administrative procedures to ensure agency fidelity to a particular substantive deal. ${ }^{79}$ All in all, a less risky course would be for the original coalition to codify the substantive bargain as precisely as possible. ${ }^{80}$ Delegating authority in broad terms only increases the chance that the agency will go astray and does not seem to be an effective way to serve the special interests of the original coalition.

The controversy over power plant emission standards illustrates the difficulty of defending broad grants of agency discretion on the grounds that such discretion ensures outcomes that benefit particular coalitions of interest groups. Although one might claim that the ultimate EPA decision confirms that agencies serve the interests of enacting coalitions, the EPA came very close to setting a sulphur emission standard that would have denied the eastern coal producers benefits they believed were owed to them under the Act's 1977 amendments. ${ }^{81}$ Moreover, environmentalists - the other major group in the coalition - felt that their interests were unduly sacrificed by the EPA decision. ${ }^{82}$ If Congress's deal truly was to guarantee that highsulphur coal remained a viable alternative for new power plants, the statute should have explicitly required the EPA to adopt a scrubbing requirement, rather than give the EPA discretion over whether to do so. Stated more generally, even if a statute appears aimed at furthering the interests of a particular coalition, allowing an agency broad regulatory discretion creates risks that the agency will undermine the interests of the enacting coalition. If the pluralistic model really mo-

significant voice in the process through presidential influence, which allowed the Department to oppose coal scrubbing at a time when both major interest groups in the enacting coalition eastern coal producers and environmentalists - favored scrubbing. See Ackerman \& Hassler, supra note 59 , at $1542-43$.

78 See Robinson, supra note 75 , at $492-93$.

79 There is no evidence that Congress uses statutorily prescribed administrative procedures to protect substantive legislative bargains. If Congress often did so, one would expect to find significant variations in such procedures rather than the few archetypes that seem to predominate. See id. at $489-90$.

${ }^{80}$ See Jeffery S. Hill \& James E. Brazier, Constraining Administrative Decisions: A Critical Examination of the Structure and Process Hypothesis, 7 J.L. ECON. \& ORG. 373, 374 (1991).

${ }^{81}$ In fact, despite the procedural opportunities for eastern coal interests to "throw their weight around," it appears that a last minute appeal by Senate Majority Leader Byrd, who not coincidentally represents the eastern coal-producing state of West Virginia, was instrumental in "persuading" the EPA Administrator to adopt an implicit scrubbing requirement. See Ackerman \& Hassler, supra note 59 , at $1552-54$.

82 Of the affected interest groups, only the environmentalists and power companies challenged the EPA standards in court. See Sierra Club v. Costle, 657 F.2d 298, 312-13 (D.C. Cir. 1981). 
tivated most regulation, one would expect regulatory statutes to contain much more detailed provisions limiting agencies' abilities to deviate from legislatively struck deals.

The prior discussion is not meant to show that previously advanced theories of agency decisionmaking provide no justification for some of the policy-setting discretion that characterizes the administrative state. It merely demonstrates that they do not explain, let alone justify, many legislative delegations of decisionmaking authority to the bureaucracy. I simply contend that civic republicanism provides a more coherent theoretical foundation for the bureaucratic state.

\section{Civic Republicanism - Its Promises and Its Pitfalls}

\section{A. Civic Republicanism Defined}

Civic republicanism has evolved as a concurrence of liberal and republican theory that simultaneously seeks to foster individual freedom from government-imposed values and freedom collectively to define the values of the relevant political community. ${ }^{83}$ According to civic republicanism, the state acts legitimately only if it furthers the "common good" of the political community. ${ }^{84}$ Unlike more traditional republican theories, civic republicanism neither posits some external conception of the common good nor relies on some elite body to define it. Instead, civic republicanism embraces an ongoing deliberative process, inclusive of all cultures, values, needs, and interests, to arrive at the public good. ${ }^{85}$ Civic republicans see the development of a conception of the common good as a fundamental purpose of democracy - a purpose necessary for individual self-identity and self-fulfillment. ${ }^{86}$.

Civic republicanism also posits that no individual acting in her political capacity should be subservient to other political actors. ${ }^{87}$ Hence, the theory does not equate the public good that legitimates government action with majority rule. Social consensus about what

83 See Sunstein, supra note 12, at 1566-71.

84 See Ackerman, supra note 10, at 1020; Michelman, supra note 10, at 18-19; Sunstein, supra note 12, at 1547-48; Reich, supra, note 13 , at $1631-32$.

85

[T] conditioned by a shared social context that helps constitute that person's identity. This social context consists not only of networks of personal relationship but also, more fundamentally, of language, culture, and their influence on how we perceive the world.

Michelman, supra note Io, at $\mathbf{3 2}$.

86 See id. at 18-I9.

${ }^{87}$ See Sunstein, supra note 12, at 1550. 
is best for the community as a community, ${ }^{88}$ not as the aggregation of individuals' private interests, is the defining feature of the common good. ${ }^{89}$ Government's political decisions - that is, the law - must embody this consensus of the common good.

Civic republicanism does not ignore individuals' private interests or the culturally and historically defined values from which these interests derive. ${ }^{90}$ It does, however, encourage people to understand and empathize with others whose values reflect different experiences and cultural backgrounds. ${ }^{91}$ It assumes that the deliberative process, if properly structured, will transform these values and ultimately reveal commonalities shared by different citizens. It is this transformative power of politics that enables the polity to reach consensus about the common good. ${ }^{92}$ Through the transformative power of politics, citizens are able to define the community norms that restrict the behavior of all community members, yet that all accept as just.

The ideals of civic republican theory translate into general operative criteria that good government must satisfy. First and foremost, the demand for deliberative government means that before the government acts, it must engage in public discourse about whether the action will further the common good. ${ }^{93}$ Public debate and discussion foster widespread awareness of other citizens' views of the public

es See id. at 1550 ; $c f$. Michael J. Sandel, Justice and the Good, in LIBERALISM AND ITS CRITICS 159,167 (Michael J. Sandel ed., I984) (describing a community as embodied in the participants' institutions and distinct from their plans of life).

${ }^{89}$ See Sunstein, supra note 12 , at 1548 , 1554-55. Thus, civic republican deliberation to achieve consensus differs from negotiation to reach an outcome acceptable to all. Negotiation implicitly assumes a trade-off of private interests to arrive at a compromise. Deliberation involves an ongoing attempt at persuasion that has the potential to alter how all participants view the contested subjects of debate. See Michelman, supra note II, at 1512-13; Sunstein, supra note 12 , at 1549 .

Civic republicanism does not assert that a political community can achieve consensus at every level on every issue. The costs of deliberation make this both impossible and unwise. See JoN ElSTER, SOUR GRAPES $38\left(\mathrm{I}_{9} \mathrm{8}_{3}\right)$. Sometimes compromises will represent the best resolution of an issue because of barriers to universal consensus. See Sunstein, supra note I2, at 1555. Still, within a civic republican framework, the process of deliberation increases understanding of the positions of others and thereby facilitates outcomes that are accepted as closer to the ideal and hence more democratic and just. See infra pp. 1534-35, 1539.

90 In practical terms, it is probably impossible to envision discourse about public values that is "external to private beliefs and values." Sunstein, supra note 12, at 1549 .

${ }^{91} \mathrm{Cf}$. $i d$. at 1550 ("The requirement of deliberation is designed to ensure that political outcomes will be supported by reference to a consensus (or at least broad agreement) among political equals.").

92 See Michelman, supra note II, at 1505-06, 1512-15; Sunstein, supra note 12, at 1549. The reliance on the transformative capacity of political deliberation aligns civic republican theory with the philosophy of Jurgen Habermas, who has asserted that "practical discourse" an ideal speech situation - provides the means of validating normative claims through revelation of generalizable interests. See Richard J. Bernstein, Beyond ObJectrvisM ANd ReLativisM 187 ( 1983$)$.

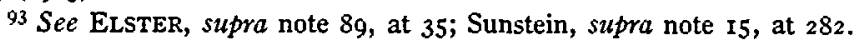


interest and thereby facilitate consensus. Deliberative government also requires that the decisionmaker, be it the President, legislature, judge, or agency, explain how its decisions further the common good. ${ }^{94}$ This requirement guards against political "deals" that advance the private interests of particular factions within society. ${ }^{95}$ Explanation by the decisionmaker also promotes understanding of how government action relates to the common good and thus encourages acceptance of that action.

The civic republican goal that government policy reflect political consensus requires open access to the policymaking process. ${ }^{96}$ Representatives of all interests potentially affected by a government action must have meaningful opportunities to engage in discussion about the action. ${ }^{97}$ Feedback from the decisionmakers to the people is equally important; it allows the decisionmaking process to influence individual value formation. Broad rights of access serve both of these requirements. They allow champions of particular values to communicate their perspectives to government decisionmakers, and they facilitate the decisionmakers' communication of the reasons for their decision - how their decision takes account of various perspectives - to the citizenry.

Interest groups may be essential, if civic republicanism is to achieve its ideal of political access and input, because they consolidate people with common private interests and backgrounds. Interest groups streamline the input that the government receives but ensure that the interests of diverse parties are represented. Interest group representatives can, in turn, provide feedback to group members

94 Thus, Martin Shapiro has characterized the courts' recent call for more complete and persuasive explanation of rulemaking decisions as a conversion of administrative law from a pluralist to deliberative basis. See SHAPIRO, supra note 4, at I68. And, although not explicitly invoking republican thought, Gerald Gunther's call for more meaningful rationality review of legislation, tying review to the actual motivation of the legislature, essentially applies this criteria of deliberation to the legislative process. See Gerald Gunther, The Supreme Court, I97I Term - Foreword: In Search of Evolving Doctrine on a Changing Court: A Model for a Newer Equal Protection, 86 HARV. L. REV. I, 2 I (I972).

${ }^{55}$ See ELSTER, supra note 89, at 35-36; $f f$. Henry J. Friendly, Chenery Revisited: Reflections on Reversal and Remand of Administrative Orders, I969 DuKE L.J. 199, 206-17 (discussing cases in which agency decisions were reversed and remanded for a failure to state adequate reasons for the decisions).

${ }^{96}$ Access also serves the republican commitment to citizenship, which emphasizes individual participation in the process of defining self and community. See Paul Brest, Further Beyond the Republican Revival: Toward Radical Republicanism, 97 XALE L.J. I623, I623-24 (I988); Hannah F. Pitkin, Justice: On Relating Private and Public, g PoL. THEORY 327, 347-49 (I981).

${ }_{97}$ See, e.g., SunSTEIN, supra note $\mathrm{I}_{3}$, at 212-14. If universality is to be achieved, the only alternative to access is the exclusion of those individuals whose values differ from the political community. This was the route taken by many traditional republicans and arguably by the Federalists, see Charles A. BEARD, AN ECONOMIC INTERPRETATION OF THE CONSTITUTION OF THE UNITED STATES 249-52, 324-25 (1935), but one rejected by present-day advocates of civic republicanism, see Sunstein, supra note 12 , at 1569 . 
about how the government's ultimate decision addresses their particular concerns. Although interest groups are not currently organized primarily to provide such give-and-take between group members and leaders, intra-group communications can influence members' frameworks for understanding and evaluating government action.

It may seem paradoxical that civic republicanism, which eschews the primacy of private interests in favor of a common good, must rely on groups organized around private interests. ${ }^{98}$ In fact, however, citizen participation in an interest group, and in the definition of the group's values and goals, can provide an outlet for participatory rather than representative community self-determination. ${ }^{99}$ In other words, the tension between republican citizenship and the Madisonian notion of representative government is not so great if one views the formation and identification of "private" interest groups - groups that may include churches, labor unions, civic associations, and even corporations and local governments - as part of the deliberative process. There is no inconsistency as long as the political role of interest groups is to debate the common good from their unique perspectives, and not intransigently to pursue their private concerns. ${ }^{100}$

The civic republican condition that political participants not be subservient to one another mandates that government decisionmakers have equal regard for all interests. ${ }^{101}$ No private preference is a priori illegitimate; a private interest may be deemed illegitimate only if the deliberative process reveals it to be inconsistent with universally shared norms of ethics or justice. Decisionmakers should evaluate the positions of participants in the political process by the persuasiveness of their arguments and not by the identity, status, or number of individuals supporting each position. ${ }^{102}$ It is not enough that a decision garners popular support or that it accurately reflects a political bargain that furthers the private interests of a majority of citizens; to be legitimate, a decision must respect the positions of all interest

98 Cf. Sunstein, supra note 12, at 1573-74 (noting the potential of private "intermediate organizations" for encouraging citizenship, but also noting the dangers posed if such organizations are not themselves subject to constraints).

99 See Peter M. Blau, Exchange and Power in Soclal Life 34-38 (I964); Robert H. Salisbury, An Exchange Theory of Interest Groups, I3 MIDWEST J. POL. SC1. I, 16 (1969). A theory of civic republicanism that allows organized participation in national government through interest groups begins to respond to Paul Brest's critique that civic republicanism fails to sufficiently involve the citizen in government. See Brest, supra note 96 , at $1625-26$.

100 But see Kathleen M. Sullivan, Rainbow Republicanism, 97 YALE L.J. 1713, 1721 (1988) (arguing that private voluntary associations are "too homogeneous, too partial, [and] too differentiated" to form the groundwork for a civic republican system).

101 See Sunstein, supra note 12, at 1552-53. Frank Michelman suggests that civic republicanism's "dialogic, critical-transformative dimension" cannot even take place without the stimulation of nonmainstream views by those at the margins of society. Michelman, supra note II, at $1529-30$.

102 See EISTER, supra note 89 , at $35-36$. 
groups and respond to their arguments in terms of the good of the community.

These operative criteria do not necessarily invalidate compromises among different interest groups. In some situations, compromises might serve the common good. ${ }^{103}$ For example, although most religious groups feel strongly that their beliefs are correct, the common interest may be best served by an agreement to tolerate all religions and to demand that the government not prefer some over others. ${ }^{104}$ In the bailiwick of more traditional regulation, the pricing of natural monopoly goods, such as utility service, may be best accomplished by a political determination of the fair share that each class of customers should contribute to fixed costs - a deal splitting the costs over and above marginal cost. 105 In other words, civic republicanism does not condemn all government decisions that explicitly divide benefits between interest groups; rather, it condemns those deals reached by groups that barter with the currency of electoral power to further prepolitical private interests.

Although civic republicanism makes optimistic assumptions about the government's capacity to act deliberatively, it recognizes that the natural tendency of human beings, at least in large measure, is to act in their self-interest. ${ }^{106}$ It therefore calls for institutional structures to

${ }^{103}$ For example, the achievement of a consensus about a particular government decision may be impractical or so expensive that achieving consensus is not in the public interest. In such a case, the public interest might best be served by a consensus on a meta-principle that a compromise is appropriate. For further discussion of compromise as part of deliberative politics, see Elaine Spitz, Majority Rule 213-14 (I984); and Stephen K. White, The Recent WORK OF JURGEN HABERMAS 75-77 (I988).

104 Sunstein has stated that civic republicanism is not opposed to rights and has asserted that "religion . . . should be entirely off-limits to politics." Sunstein, supra note I2, at I555. I agree with this view if Sunstein means to assert more precisely that he perceives a nearly universal consensus that such matters should be left to individuals as a matter of private right or that there is consensus that discourse will never resolve actual religious questions and hence will be unjustifiably costly and fractious. See id. at 1555 n.85; Stephen Holmes, Gag Rules or the Politics of Omission, in Constitutionalism AND Democracy ig, 49 (Jon Elster \& Rune Slagstad eds., 1988). In addition, civic republican theory may permit a notion of rights as a sphere of freedom from government intervention that is presupposed by the deliberative process - a sphere that frees citizens to develop their capacities to engage in the critical dialogic process of defining their communities. See, e.g., C. Edwin Baker, The Process of Change and the Liberty Theory of the First Amendment, 55 S. CAL. L. REV. 293, 337-44 (1982). This sphere might include religion.

${ }^{105}$ As long as no particular class of customers exhibits significant elasticity of demand, there is no economic basis for apportioning these fixed costs. There may, however, be other bases, such as the relative wealth of classes of customers or a desire to redistribute wealth more equitably. See I AlFred E. Karin, The Economics of REgULATion I44-46 (I970).

${ }^{106}$ See Sunstein, supra note 1o, at 49; $c f$. THE FEDERALIST No. 55, at 346 (James Madison) (Clinton Rossiter ed., 196r) ("As there is a degree of depravity in mankind which requires a certain degree of circumspection and distrust, so there are other qualities in human nature, which justify a certain portion of esteem and confidence."). 
ensure against regulations meant merely to serve particular factions' private interests. ${ }^{107}$ Limiting factional influence was the rationale given by the Federalists for the separation of powers, a bicameral legislature, indirect election of the President and the Senate, and the dual system of state and federal government. ${ }^{108}$ These structural safeguards, however, frequently have proven unable to prevent regulators from acting in a pluralistic rather than in a civic republican fashion. The question remains how best to structure government to achieve the civic republican ideal, and this, in turn, depends on understanding the potential benefits and detriments of civic republican theory and how they might be realized or avoided.

\section{B. The Promise of Civic Republicanism}

The appeal of civic republicanism derives both from the richness of the role it defines for citizens - to determine the identity of their political community - and from its explicit attempt to counter factional competition. Pluralism accepts factionalism as a given and defines the public interest as an aggregation of private values. ${ }^{109} \mathrm{By}$ doing so, pluralism denies the importance of community and thereby precludes many regulatory outcomes that might prove fulfilling to the entire populace in the long run. In fact, pluralistic democracy reveres the pursuit of private interest, for to enhance individual private interest is to enhance the aggregate of such interests. ${ }^{110}$ Pluralistic democracy therefore considers debate about the legitimacy of the values enhanced by government action unnecessary as long as those values accurately reflect the bargain struck by interest groups participating in a "fair" democratic process. ${ }^{111}$ Thus, under pluralistic democracy, the state may actually end up pursuing values that the political community, after deliberation, would universally consider repugnant. ${ }^{112}$ At best, by cordoning off discussion about the legiti-

${ }^{107}$ See Michael A. Fitts, Look Before You Leap: Some Cautionary Notes on Civic Republicanism, 97 YALE L.J. I65I, I652 (I988).

108 See, e.g., The Federalist No. 5I, at 320-25 (James Madison) (Clinton Rossiter ed., 1961); THE Federalist No. 68, at 345 (Alexander Hamilton) (Clinton Rossiter ed., 196I).

${ }^{109}$ See Sunstein, supra note 12, at 1543; see also Richard A. Epstein, Modern Republicanism - Or the Flight from Substance, 97 YALE L.J. I633, I639 (I988) (describing pluralism as accepting that "there is no collective way to define what constitutes the good life").

110 See David Held, Models of Democracy i87-88 (1987); Adam SMith, AN INQuiry into the Nature and CaUses of the Wealth of Nations 421 (Edwin Carran ed., I937).

111 See Sunstein, supra note 12, at 1542-43.

112 See id. at $1543-44$. "Bad preferences," to use Sunstein's terminology, might result from a victimized group's adapting its preferences to available opportunities. See ELSTER, supra note 89 , at 109-I I. They might also occur if beneficiaries of existing practices alter their beliefs to reduce "cognitive dissonance" between their conduct and their moral values. See George A. Akerloff \& William T. Dickens, The Economic Consequences of Cognitive Dissonance, 72 AMr. ECON. REV. 307, 308-09 (1982). 
macy of values, pluralistic democracy implicitly lends legitimacy to existing mainstream values, which not surprisingly mirror those of the historically dominant culture. ${ }^{113}$ In contrast, by insisting that government actions reflect social consensus about the common good, civic republicanism facilitates the adoption of law that respects the interests of minorities and other groups historically excluded from political power ${ }^{114}$ and that simultaneously comports with the polity's general sense of justice. This facilitation, however, can occur only if the decisionmaking process includes representatives of groups normally excluded from the political process or so frustrated by it that they have become apathetic or even alienated.

Regulating by deliberate decisionmaking also enriches the polity's choice of values by expanding the impoverished subset of governmental choices made available by pluralistic democracy. Not only may regulation correct imperfections in the market's ordering of private preferences, it may also legitimately embody the community's collective desires. Participation in the political process of defining those collective desires enables individuals to attain a sense of both selffulfillment and community identification. ${ }^{115}$ The law may satisfy citizens' altruistic preferences, which often conflict with their immediate, self-interested desires. It may also allow the realization of secondorder preferences - "wishes about wishes" - such as protecting cultural diversity or ensuring economic equality. Finally, civic republican law may precommit individuals to a course of conduct that each considers to be in his best interest, but from which he fears he will deviate if left to his own devices. ${ }^{116}$

In addition to legitimizing an expansive role for government regulation, discourse can enlighten participants about potential community norms. Such education might foster creativity, leading participants to construct regulatory schemes that they would not have considered had the political process aimed at coalition-building and compromise rather than community consensus. ${ }^{117}$ In sum, identifi-

113 This is the political analogy to a critique of the economic principle of pareto optimality - that it takes the initial distribution of wealth as given even though the initial distribution greatly affects the final economic state. See Sunstein, supra note I3, at 39; John T. Donohue III, Law and Economics: The Road Not Taken, 22 LAW \& Soc'y Rev. 903, 906-08 (1988).

114 See Sunstein, supra note 12 , at $1575-76$. In this regard, modern civic republicanism departs quite drastically from its traditional republican roots. The tendency of republican theory to exclude those outside the mainstream culture has led some commentators to question whether particular processes of deliberative government can effectively include the voices of minorities and the disadvantaged. See Derrick Bell \& Preeta Bansal, The Republican Revival and Racist Politics, 97 YALE L.J. I609, I612-13 (1988); Fitts, supra note 107, at 1660-6r; Linda K. Kerber, Making Republicanism Useful, 97 YALE L.J. I663, I669 (I988).

115 See Robert P. WOLfF, The Poverty of Liberalism Ig0-93 (I968).

116 See SunSTEIN, supra note $I_{3}$, at 59.

117 See Reich, supra note 13 , at 1636. 
cation of the community as a distinct entity that influences the selfdefinition of its members encourages the government to adopt a supportive role that can enhance individual feelings of happiness and selfworth. ${ }^{118}$ Some commentators have even suggested that participation in determining the identity of the political community is itself a good, thereby rendering civic republicanism inherently as well as instrumentally valuable. ${ }^{119}$

Civic republicanism also promises to minimize distortions in the democratic process. In the pluralist world of competing factions, elected officials are supposed to constrain regulators to set policy in accordance with the number of people who support the policy and the intensity of their support. 120 Unfortunately, the magnitude and intensity of citizen views regarding all but the most salient regulatory controversies have relatively little effect on elections. Instead, the aggregate wealth of interest groups, the power and status of their members, and the existing political power of incumbents greatly distort electoral outcomes. ${ }^{121}$

Even if the democratic process started out undistorted, it most likely would not stay that way. Without a "public interest" constraint, legislatures have incentives to create and distribute "monopoly rents"122 to interest groups that support incumbents. These incentives enhance the wealth and power of interest groups, create economic disparities that allow "reinvestment" in incumbent reelection, and make reelection more likely. ${ }^{123}$ Public choice theorists bemoan un-

"11 See id. at 1637 .

${ }^{119}$ See Brest, supra note 96 , at 1624 ; Pitkin, supra note 96, at 344-45.

120 See HeLd, supra note 110 , at $192-95$.

${ }^{121}$ This realization has sparked great concern about the influence of political action committees and the fact that the success rate for United States Representatives who seek reelection is between ninety and ninety-eight percent. See Herbert E. Alexander, Financing Politics: Money, Elections, and Political Reform 185 (3d ed. I984); MoRris P. Fiorina, CONGRESS: KEYSTONE OF THE WASHINGTON ESTABLISHMENT II6 (2d ed. 1989). Interestingly, concerns about unequal influence due to wealth and privilege were recently expressed by Robert Dahl, perhaps the preeminent trumpeter of pluralistic democracy. See ROBERT DAHL, A PREFACE TO ECONOMIC DEMOCRACY 54-55 ( 1985 ).

122 I use the term "monopoly rents" in a limited sense to refer to the excess profits that entities in economic markets can earn because the government has legally restricted or biased the workings of these markets. See James M. Buchanan, Rent Seeking and Profit Seeking, in Toward a Theory of THE Rent-Seeking Society 3, 8-i I (James M. Buchanan, Robert D. Tollison \& Gordon Tullock eds., I980); George Stigler, The Theory of Economic Regulation, 2 BELL J. ECON. \& MGMT. SCI. 3, 3 (I97I).

${ }^{123}$ See James D. Gwartney \& Richard E. Wagner, Public Choice and the Conduct of Representative Government, in Public Choice and Constitutional Economics 3, I9-20 (James D. Gwartney \& Richard E. Wagner eds., I988); Michael E. Levine \& Jennifer J. Forrence, Regulatory Capture, Public Interest, and the Public Agenda: Toward a Synthesis, 6 J.L. ECoN. \& ORG. 167, I69-70 (1990). But cf. James Q. Wilson, The Politics of Regulation, in THE Politics of REgulation 357, 357-63 (James Q. Wilson ed., I980) (arguing that the rent seeking theory does not accurately describe much of regulatory politics). 
constrained congressional power precisely because they fear that the motive to create monopoly rents is so powerful and pervasive that it necessarily renders the legislative process a socially wasteful contest for such rents. ${ }^{124}$ In sum, pluralism invariably produces political distortions that serve to perpetuate existing bases of economic and political power. Civic republicanism attempts to overcome this systematic bias by requiring the state to justify its decisions in terms other than the promotion of interests of politically influential factions.

\section{The Potential Pitfalls of Civic Republicanism}

Because civic republican theory envisions a broader array of government activity than a theory that credits only the pursuit of private wants, ${ }^{125}$ the theory also creates a potential for abuse that some fear may be worse than the factionalism that it tries to alleviate. ${ }^{126}$ First, civic republicanism may facilitate the pursuit of private ends by the politically powerful. Second, it may grant the state substantial latitude to impose on the populace what is in fact an inaccurate conception of the common good.

Fears that civic republicanism may increase enforcement of private-interest deals stem from the belief that there is no common good apart from the aggregate of individuals' private preferences. ${ }^{127}$ The civic republican response draws upon the intuition that if one asks individuals what is good for society and what is good for them personally, one will usually get different answers. ${ }^{128}$ Individuals arrive at conceptions of the public interest in part by imagining what it would be like to be in the shoes of others - by empathizing with the problems and aspirations of citizens from different backgrounds who have different needs and wants. Each individual has some subjective

124 The creation of monopoly rents, in the political context, is inefficient because those who are outside the beneficiary group pay more in competition costs, increased prices, and taxes than the successful interest group realizes in extra profits. See Anne O. Krueger, The Political Economy of the Rent Seeking Society, ${ }_{4}$ AM. EcoN. REV. 29I, 30I-02 (1974); Gordon Tullock, Rent Seeking as a Negative-Sum Game, in TOWARd a THEORY OF THE RENT-SEEkING Society, supra note 122 , at $17,19-31$.

125 See supra notes II $5-116$ and accompanying text.

126 According to Jonathan Macey:

Two of the most salient lessons of history are the mixed success of governmental efforts to do good on the one hand and the awesome success of the government when it turns its hand to hatred and destruction on the other. It is in light of these intractable lessons that Sunstein's reliance on civic virtue assumes an ominous dimension.

Jonathan R. Macey, The Missing Element in the Republican Revival, 97 YALE L.J. I673, I684 (1988) (footnotes omitted).

${ }^{127}$ See, e.g., Buchanan \& Tullock, supra note 8, at II-15, 284-85; Don Herzog, Some Questions for Republicans, I4 POL. THEORY 473, 476-77 (1986).

${ }^{128} C f$. Sunstein, supra note 12 , at 1550 (arguing that the republican requirement of civic virtue "refers simply to the understanding that in their capacity as political actors, citizens and representatives are not supposed to ask only what is in their private interest, but also what will best serve the community in general"). 
notion of the common good - a notion that embodies public values shared with others in the community. ${ }^{129}$ Civic republicanism requires that the government base its actions on these public values rather than on the private desires that citizens bring into political discourse. ${ }^{130}$

Another criticism that raises the specter of private dealmaking asserts that even if a common good does exist, individuals will inevitably pursue their self-interest. ${ }^{131}$ This inevitability suggests that the operative elements of civic republicanism - discussion and debate, access, and substantive checks by independent institutions against the pursuit of self-interest - will not preclude politically powerful groups from cutting deals to serve their separate interests. The current failure of checks and balances in the federal government to constrain factional politics gives credence to this concern. Deliberation, however, should not simply be dismissed as an ineffective moderating influence on factional conduct.

In many instances, people do not recognize that their political positions stem from personal experiences and values. They may not be aware of other conceptions of the public interest or understand how their conception would affect those who differ from them.132 They may also "delude" themselves into thinking that the values that guide their self-interested behavior accord with the public interest. ${ }^{133}$ By informing citizens about others' conceptions of the public interest and by revealing to them how their own conceptions might harm others, the deliberative process can help educate citizens and unmask self-delusions. ${ }^{134}$ In addition, requiring explanation of government

129 The civic republican notion of the common good stems from what Michael Sandel terms "a commonality of shared self-understanding." SANDEL, supra note Io, at I82. Even political economists such as James Buchanan and Gordon Tullock concede that individuals do entertain subjective conceptions of the public good, although they deny that these conceptions can provide the basis for a more universal notion of the public interest except by the imposition of one individual's conception of the public interest on another. See BUCHANAN \& TulLack, supra note 8 , at 284 .

${ }^{130}$ See Sunstein, supra note 12 , at $1554-55$.

131 See, e.g., Buchanan \& Tullock, supra note 8, at 27-28; Epstein, supra note 109, at I637-39; Macey, supra note 126 , at $1678-79$.

132 See ELSTER, supra note 89, at I12-13.

133 People "tend . . . to see their own behavioral choices and judgments as relatively common and appropriate to existing circumstances while viewing alternative responses as uncommon, deviant, or inappropriate." Lee Ross, David Greene \& Pamela House, The "False Consensus Effect": An Egocentric Bias in Social Perception and Attribution Processes, 13 J. EXPERIMIENTAL Soc. Psychol. 279, 280 (1977).

${ }^{134}$ See ELSTER, supra note 89 , at $36-37$. To the extent that the lack of a universally acceptable conception of the public interest stems from various interest groups' attributing a false consensus to their own values, the deliberative process has the potential to correct this mistaken attribution by making individuals' "sampling and retrieval of evidence" more accurate and by counteracting through discussion their "idiosyncratic interpretation of situational factors and forces." Ross, Greene \& House, supra note I33, at 299. 
decisions will sometimes prevent decisionmakers from crediting raw political power. Some political deals simply cannot be justified persuasively in principled terms. ${ }^{135}$ At least at the margin, the prospect of an independent review to ensure reasoned decisionmaking will deter interest groups from striking deals. ${ }^{136}$ Finally, if courts seriously required an agency to explain why a change in policy better serves the public interest than does the status quo, regulators would hesitate to give post hoc rationalizations for unprincipled political decisions. The agency's past explanations of its policies would frame the debate about present controversies; the whole vocabulary for the discussion of a policy choice would depend on principles announced in previous decisions. An agency that provided reasons truly unrelated to the actual basis for a decision might find itself hamstrung by a policy that it never wanted to adopt.

In short, the human propensity to pursue self-interest is not fatal to civic republican theory. Civic republicanism explicitly recognizes this propensity and responds by demanding institutional constraints that discourage such pursuits. Instead of undermining the call for a civic republican political norm, the strong tendency to act in one's self-interest highlights the need for such a norm. The suggested alternative - constraining government to limit the influence of humanity's evil tendencies - provides no answer to those without the means to compete in a society of purely private transactions ${ }^{137}$ or to those who see their identity as bound with that of their community.

Even if government pursues what it perceives to be the common good, one might fear that the state will impose a mistaken conception of that good, especially if one doubts the citizenry's ability to achieve

135 An example of which I have personal knowledge involved a New York State Public Service Commission (PSC) decision that allocated a tax refund between a utility and its ratepayers. The refund stemmed from statutorily sanctioned changes in the utility's operations in the wake of damage to one of its power plants from a rock slide on the Niagara River. The PSC reasoned that the slide had caused utility customers to pay higher rates and had cut into shareholder profits. Without evaluating these losses precisely, the Commission decided to split the refund equally between shareholders and ratepayers. The state's intermediate appellate court remanded the decision on the grounds that the Commission's decision was arbitrary and capricious: because both parties to the suit had presented detailed evidence on the question of loss, the Commission was duty-bound to allocate the refund in accordance with the evidence in the record. See Niagara Mohawk Power Co. v. Public Serv. Comm'n, 476 N.Y.S.2d 396, 400 (N.Y. App. Div. 1984). To the amazement of many in the PSC's Office of Counsel, the New York Court of Appeals reversed and upheld the PSC decision. Because it granted such broad discretion to the PSC to balance the equities, the court effectively relieved the Commission of any meaningful requirement to explain its decision based on the record. See Niagara Mohawk Power Co. v. Public Serv. Comm'n., 485 N.E.2d 233, 236 (N.Y. 1985).

136 Other students of administrative decisionmaking, however, believe that the explanation requirement is unhelpful. See, e.g., Joseph L. Sax, Enrichment Series: The (Unhappy) Truth About NEPA, 26 OKLA. L. REv. 239, 239 (1973).

137 See Charles A. Reich, The New Property, 73 YALE L.J. 733, 737-38 (1964). 
consensus about the public interest. ${ }^{138}$ Certainly such doubts have foundation: one should not expect a consistent set of answers from different individuals who are asked whether a specific government program furthers the common good. In the absence of consensus, government might allow officials to mask imposition of the mainstream culture's values on the rest of the populace. Worse yet, a regulator might impose her personal conception of the common good as the law. ${ }^{139}$

The hope of civic republicanism, however, is that deliberation about a more abstract level of principles will yield consensus. Particular governmental decisions then can, and to be legitimate, must, conform to these principles. ${ }^{140}$ Although appeal to meta-principles may facilitate agreement, I am skeptical that society can ever reach a universal consensus about them. The process of deliberation, however, frequently enables society to come close, in the sense of arriving at a set of principles to which most citizens would agree. ${ }^{141}$ Moreover, civic republicanism's explicit call for persuasion of others as the goal of the deliberative process is likely to discourage adoption of egregiously coercive principles. ${ }^{142}$ Any coercion that then results is likely to be more just and democratic (that is, it will come closer to conforming to the public values of a greater proportion of the citizenry) than the coercion that may accompany a system of factionalism and political barter. The potential for coercion, however, cannot be ignored: any system established to implement a civic republican democracy will be somewhat coercive. ${ }^{143}$ One must therefore take care to

13\$ See ZIEgler \& PEAK, supra note 53, at 2I-23; Herzog, supra note 127 , at 488-89; see also Iris M. Young, Polity and Group Difference: A Critique of the Ideal of Universal Citizenship, 99 ETHICs 250, 254-55 (I989) (noting that early American republicans used the myth of a universally shared perspective to exclude those outside the dominant culture from political participation).

${ }^{139}$ See Joseph P. Kalt \& Mark A. Zupan, The Apparent Ideological Behavior of Legislators: Testing for Principal-Agent Slack in Political Institutions, 33 J.L. \& EcoN. 103, 103-04 (1990); Joseph P. Kalt \& Mark A. Zupan, Capture and Ideology in the Economic Theory of Politics, 74 AM. ECON. REv. 279, 298 (1984) [hereinafter Kalt \& Zupan, Capture and Ideology].

${ }^{140}$ For example, Michelman's republican critique of the Supreme Court's decision in Bowers v. Hardwick, 478 U.S. 186 ( 1986 ), stems from an assertion that although there is no consensus on the morality of homosexuality itself, there is a shared understanding that "homosexuality has come to signify not just a certain sort of inclination that 'anyone' might feel, but a more personally constitutive and distinctive way, or ways, of being." Michelman, supra note I I, at 1533. Hence, to be legitimate, government decisions regarding homosexuality must be consistent with this shared understanding.

${ }^{141} \mathrm{Cf}$. Sunstein, supra note 12, at 1555 ("The republican position is not that every issue is subject to political resolution; it is instead that some questions can yield general agreement through deliberation. A conception of politics that disregards this fact will be doomed to repeat the failings of pluralism.").

142 See Bernard Manin, On Legitimacy and Political Deliberation, 15 Pol. THeory 338, 357-59 (Elly Stein \& Jayne Mansbridge trans., I987).

${ }^{143}$ Coercion, however, is inherent in any system of binding law. Even full participatory 
set up a decisionmaking process that minimizes the potential for coercion.

One might also distrust the leeway that civic republican theory grants the state because the state's adoption of a particular conception of the public good will not necessarily lead to unique legal or policy outcomes. ${ }^{144}$ Non-unique outcomes, however, do not necessarily condemn civic republican theory. In fact, majoritarian voting schemes upon which pluralist theory relies suffer from the same defect. ${ }^{145}$ Civic republicanism does not require that the common good ultimately determine every state action. It remains a useful model of government as long as pursuit of the common good places constraints on decisionmakers that lead them to reach more just and acceptable outcomes than would result under other theories. The hope is that choosing policy to comport with basic values derived through deliberation will reduce disagreements that stem from fundamental value inconsistencies.

Finally, critics of civic republicanism object that its insulation of decisionmakers from immediate political pressure leads to undemocratic outcomes. ${ }^{146}$ By disdaining direct electoral checks, the theory gives policymakers little incentive to discover deliberatively determined community values or to examine how the values bear on the issues before them. This disdain might lead to either of the two dangerous pitfalls of civic republicanism: government that serves powerful private interest groups or government that implements regulators' personal conceptions of the common good. ${ }^{147}$

This criticism highlights a fundamental tension in civic republican theory. The theory relies on the citizenry to define community values,

democracy with a rule of unanimity is coercive, because the failure to act is equivalent to deciding to maintain the status quo, a decision with which some may disagree.

${ }^{144}$ See SHAPIRO, supra note 4, at 2; Jerry Mashaw, As If Republican Interpretation, 97 YALE L.J. I685, I698-99 (1988).

145 See supra notes $55-57$ and accompanying text.

146 See, e.g., JeREMY RABKIn, Judictal Compulsions I4I (I989); Pierce, supra note 57, at 125I. In addition to the critiques addressed in the text, some scholars have expressed practical concerns about the costs of civic republicanism's deliberative goal. See SHAPIRo, supra note 4, at 29-30; Diver, supra note 50, at 428. One quick response is that civic republican deliberation takes into account the cost of discourse on particular issues. In other words, a regulator could legitimately stop an inquiry if she reasonably suspected that further inquiry would be costly and unlikely to alter significantly her preliminary policy determination. At a more visceral level, however, I still feel uneasy about any theory that requires a search for the best policy. To me, civic republicanism becomes more attractive if viewed not as demanding perfection, but instead as requiring that outcomes be acceptable to all after the deliberative process occurs a view premised on some variation of "incremental" decisionmaking and "satisficing." $C f$. HERBERT A. SimON, MODELS OF MAN 204-05, 24I-73 (r957) (postulating that individuals within organizations "satisfice"); Diver, supra note 50, at 399-400 (describing incremental decisionmaking).

147 See Diver, supra note 50, at 428-29. 
but distrusts the citizenry's willingness to pursue the public good. Civic republicanism demands that the law simultaneously conform with a popular consensus and yet not represent a mere polling of people's private preferences. In operative terms, one cannot subject decisionmakers to more direct political pressure without threatening the civic republican ideal that decisionmakers act deliberatively.

To resolve this tension, a civic republican decisionmaking process must explicitly choose the level of political influence that best balances the requirement of deliberation against that of popularly supported outcomes. ${ }^{148}$ This choice should depend on the attendant circumstances and the political ethic at the time the process is established. Thus, although a system of constitutional checks and balances seemed adequate to ensure congressional deliberation when the Constitution was ratified, those checks and balances may not sufficiently constrain factional influence today. ${ }^{149}$ Given such politically influential institutions as the modern press, large corporations, and private interest groups that closely monitor government decisions, the problem today is not a lack of responsiveness to popular interests, but rather an overresponsiveness to immediate and fickle political whims and to powerful factions that exercise undue influence over electoral politics. The problem is not that government will act without regard for the preferences of the politically enfranchised, but rather that the procedural balance has tipped too heavily toward political influence and away from deliberation by decisionmakers.

\section{The Administrative State as a Means of Fulfilling THE Civic Republican Promise}

Administrative agencies - the so-called fourth branch of government - may be the only institutions capable of fulfilling the civic republican ideal of deliberative decisionmaking. Congress adheres primarily to pluralistic norms and responds most directly to factional influence. Although one proponent of civic republicanism, Cass Sunstein, has sought to revitalize Congress's deliberative processes through more active judicial review, ${ }^{150}$ the size, structure, and historicallyrooted decisionmaking procedures of Congress render the prospect of revitalization unlikely. Perhaps for this reason, another proponent of

148 This is a corollary of the more general point that drawing the line between majoritarian rule and minority rights is always a political (value-laden) choice. See Paul Brest, The Fundamental Rights Controversy: The Essential Contradictions of Normative Constitutional Scholarship, 9o YALE L.J. 1063, rog6-1 105 (I981); Mark Tushnet, Darkness on the Edge of Town: The Contributions of John Hart Ely to Constitutional Theory, 89 YALE L.J. 1037, 1060-62 ( $\mathrm{rg} 8 \mathrm{so}$.

${ }^{149}$ See Sunstein, supra note ro, at $48-49$.

150 See SUNSTEIN, supra note I3, at 164 ; Sunstein, supra note Io, at 72. 
civic republicanism, Frank Michelman, has called upon the judiciary to define directly the values that underlie governmental policy and are embodied in law. ${ }^{151}$ Courts, however, are too far removed from the voice of the citizenry, and judges' backgrounds are too homogenous and distinct from those of many Americans to ensure that judiciallydefined policy will accord with the public values of the polity.

Administrative agencies, however, fall between the extremes of the politically over-responsive Congress and the over-insulated courts. Agencies are therefore prime candidates to institute a civic republican model of policymaking. Some recent administrative resolutions of tough policy choices illustrate the role that agencies can play. For example, although the American public, experts, and government officials all agreed that the United States should close some military bases, Congress was unable to close any, or even set the criteria for deciding which bases should be closed. Too many representatives found the prospect of a base closing in their district politically unacceptable. A special commission, however, was able to order base closings and do so in a fashion that took into account efficiency concerns, the need for national defense, and the economic dislocations in areas where bases will close. ${ }^{152}$

I believe that the success achieved by the Defense Base Closure and Realignment Commission was not an anomaly. The place of administrative agencies in government - subordinate and responsible to Congress, the courts, and the President - allows for the checks on agency decisionmaking that ensure politically informed discourse and prevent purely politically-driven outcomes. The bureaucratic structure of administrative agencies and the processes by which they frequently decide questions of policy also foster deliberative government. ${ }^{153}$ Consequently, as the remainder of this section outlines, the administrative state holds greater promise for a "civic republican res-

151 See Michelman, supra note I0, at 66-73; Michelman, supra note I1, at 1537; see also RONALD DWORKIN, LAW'S EMPIRE 225 (1986) (suggesting that law represents judges' interpretations of the community's "coherent conception of justice and fairness").

152 See Gwen Ifill, Public Debate on Base Closing Disorients Capital's Power Brokers, N.Y. Times, June 23, Ig9I, at AI8; cf. Michael A. Fitts, Can Ignorance Be Bliss? Imperfect Information as a Positive Infiuence in Political Institutions, 88 MrcH. L. Rev. 917, 953 n. I2 I (r990) (noting the success of the Base Closing Commission but implying that the success may have resulted from the somewhat closed nature of the Commission proceedings).

153

Administrators at least operate within a set of legal rules (administrative law) that keep them within their jurisdiction, require them to operate with a modicum of explanation and participation of the affected interests, police them for consistency, and protect them from the importuning of congressmen and others who would like to carry logrolling into the administrative process.

Jerry L. Mashaw, Prodelegation: Why Administrators Should Make Political Decisions, I J.L. ECON. \& ORG. 81, 99 (1985). 
olution" to many questions of policy than either the judicial or legislative alternatives.

\section{A. The Place of Administrative Agencies in American Government}

I. Availability of Judicial Review to Ensure Deliberative Decisionmaking. - Although the legitimacy of the judiciary stems from its use of reasoned decisionmaking, ${ }^{154}$ courts are ill-equipped to delineate the public values that flow from political deliberation. Federal judges are not politically accountable. Although political independence frees them from the pressures that encourage interest group accommodation, it also accords them great latitude to impose their subjective conceptions of the public interest on the nation. ${ }^{155}$ Courts have neither the motivation nor the means to obtain information about the values of the general polity, on which civic republicanism's common good depends. ${ }^{156}$ The federal courts are also necessarily reactive - they can legitimately decide only the issues brought before them by litigants and therefore cannot establish a policy-setting agenda. ${ }^{157}$ Courts might provide, at best, only a partial delineation of the public values and policies necessary to implement civic republican theory.

Furthermore, the courtroom is not a forum designed to develop a consensus about the public good. Procedural formality makes participation in the judicial process expensive. ${ }^{158}$ Judicial proceedings are

154 See Alexander M. Bickel, The Least Dangerous Branch 24-27 (Ig6r); Herbert Wechsler, Principles, Politics, and Fundamental Law 27-28 (ig6r).

155 See RABKIN, supra note 146 , at 141-42; Shapiro, supra note 4 , at $121-23$. This might be defensible if the judiciary mirrored the American population, but the demographics and attitudes of federal judges do not come close to representing a cross-section of American society. See Paul Brest, Who Decides?, 58 S. CAL. L. REv. 66I, 669-70 (1985).

156 See The Council on the Role of the Courts, The Role of Courts in American SocIETY $89,92-93,99$ (Jethro K. Lieberman ed., 1984). Courts lack the motivation to do so because they are not electorally accountable and because they tend to view their role as one of reasoning from past legal principles rather than from a polling of public opinion. Courts also lack the means to take polls; they depend on the parties that come before them to provide necessary information.

157 See id.; Terry M. Moe, Control and Feedback in Economic Regulation: The Case of the $N L R B, 79$ AMr. POL. SCI. REv. 1094, IrOI-02 (1985); Lawrence Susskind \& Alan Weinstein, Towards a Theory of Environmental Dispute Resolution, 9 B.C. ENVTL. AFF. L. REV. 3I1, 320 (1980).

158 See American Bar Association Action Commission to Reduce Court Costs and Delay, Attacking litigation Costs and Delay: Project Reports and Research Findings 3 (I984); Douglas J. Amy, The Politics of Environmental. Mediation ig-20 (Ig87). The expense of litigation is so great that even industry, which derives a relative advantage due to its focused interests and concentrated financial resources, has begun to look seriously at alternatives to litigation to resolve disputes. See Louis Fernandez, Let's Try Cooperation Instead of Confrontation, in BUSINESS AND THE ENviRONMENT 513, 513-19 (Kent Gilbreath ed., 2d ed. I 984 ). 
adversarial; participants focus on claiming legal entitlements and furthering their private interests. In the course of zealously advocating their individual interests, litigants lead the judicial process away from achieving true understanding and finding common ground for consensus. 159 Parties to litigation ordinarily do not adequately represent many potentially affected interest groups. They also do not tend to modify their positions in response to discourse with their adversaries. ${ }^{160}$ Contrary to the lessons of basic civics, the adversarial system is neither good at revealing the truth nor facilitating the discovery of public values.

The institutional limitations on the judiciary's ability to distill common public values suggest that courts can better serve civic republican aims by reviewing decisions of the politically accountable legislature to ensure that it engages in appropriate consensus-building deliberation. Unfortunately, judicial review of congressional decisions might, in practice, force courts to assume a primary role in defining fundamental governmental policy.

The structure and decisionmaking processes of Congress are not conducive to deliberation. Although legislative hearings nominally allow various interest groups to present and explain their positions, Congress, as a body, does not spend much time mulling over the issues and arguments raised. ${ }^{161}$ Rather, it entrusts the clarification of issues and drafting of proposed legislation to committees. ${ }^{162}$ Major committees control the legislative agenda and thereby greatly influence and constrain the outcomes reached by the full body. ${ }^{163}$ The members of these committees must consider their own constituencies and special

${ }^{159}$ Litigation-based regulation "is widely regarded as a zero-sum game in which lawyermercenaries battle in an interest group struggle from which only the lawyers profit." Richard B. Stewart, The Discontents of Legalism: Interest Group Relations in Administrative Regulation, I985 WIS. L. REV. 655, 655-56.

160 See Philip J. Harter, Negotiating Regulations: A Cure for Malaise, $7 \mathrm{I}$ Geo. L.J. I, I922 (1982); Carrie Menkel-Meadow, Toward Another View of Legal Negotiation: The Structure of Problem Solving, 3I UCLA L. REV. 754, 767-83 (1984).

161 See Michael J. Malbin, Unelected Representatives 243 (1979) (reporting that in 1977, congressional representatives spent, on average, only eleven minutes per day studying legislation). Although legislative hearings occur frequently, they are not the kind of discourse envisioned by civic republicanism. Those called to testify generally give short statements and then answer questions from committee members. See William J. KEEFE \& MoRris S. Ogul, The American Legislative Process 177-78 (6th ed. 1985). There is little opportunity for the witness to respond to the testimony of others, and committee members often ask questions as a thinly veiled means of making public statements of their views on an issue. See id. at I77 n. I3. In a sense, the hearings are a show, with interest groups sending to the Hill their bestknown, but usually not their best-informed, emissaries. See id. at 176-77.

162 See KeEFe \& Ogul, supra note I61, at I72-73.

${ }^{163}$ See William H. Riker \& Barry R. Weingast, Constitutional Regulation of Legislative Choice: The Political Consequences of Judicial Deference to Legislatures, 74 VA. L. REv. 373, 386-87 (I988). 
interest supporters; they cannot realistically be expected to perform their screening function primarily with the public interest in mind. Instead, committee members typically engage in agenda control, vote trading, and log-rolling in order to obtain votes for the regulatory legislation that they support. 164

By the time a bill reaches the floor of the House or Senate, it reflects a myriad of political bargains and compromises. Thus, even if one could characterize the floor debates as deliberative, the influence of private interest groups would still taint the legislative process. Moreover, much congressional debate reflects efforts by factions to get their preferred readings of bills on the record in the hope that a court or agency will interpret the statute in their favor. ${ }^{165}$ Often, a majority of members are absent from the floor during the so-called floor debate. ${ }^{166}$ Except perhaps when Congress debates legislation on highly publicized issues of broad public concern, the legislative process facilitates coalition building and is antagonistic to the deliberative development of consensus about the public good. ${ }^{167}$

${ }^{164}$ Cf. Arthur T. Denzau \& Robert J. Mackay, Gatekeeping and Monopoly Power of Committees: An Analysis of Sincere and Sophisticated Behavior, 27 AM. J. PoL. SCI. 740, 741-44 (1983) (discussing "sophisticated behavior" by committee members). Committee staffs do perform a valuable function by drafting legislation and by ironing out controversies so that the bills they produce are likely to pass in the main body. See Kenneth A. Shepsle \& Barry R. Weingast, The Institutional Foundations of Committee Power, 8I AM. POL. SCI. REV. 85, 89 (1987). Committees, however, go about this task by using political influence and strategic behavior to negotiate deals, not by engaging in deliberation. See KEEFE \& OGul, supra note 16r, at 32022; Malein, supra note I6r, at 245-5x; Daniel A. Farber \& Philip P. Frickey, Legislative Intent and Public Choice, 74 VA. L. REv. 423, 429-35 (1988).

${ }^{165} \mathrm{See}$ Blanchard v. Bergeron, 489 U.S. $87,98-99$ (1989) (Scalia, J., concurring in part and concurring in the judgment); Kenneth W. Starr, Observations About the Use of Legislative History, 1987 DuKE L.J. 371, 376-77. But cf. Farber \& Frickey, supra note 164, at 444-46 (suggesting the possibility that legislative history may reveal a centrist core of meaning that "generally illuminates the overall purposes of the statute").

${ }^{166} \mathrm{~A}$ statement by Representative Hechler in the Congressional Record provides a poignant indictment of conceptualizing the floor debate as a meaningful discourse about the purposes and underlying values of a piece of legislation:

Mr. Speaker, having received unanimous consent to extend my remarks in the RECORD,

I would like to indicate that I am not really speaking these words. . . . As a matter of fact, I am back in my office typing this out on my own hot little typewriter. . . . Such is the pretense of the House that it would have been easy to just quietly include these remarks in the RECORD, issue a brave press release, and convince thousands of cheering constituents that I was in there fighting every step of the way, influencing the course of history in the heat of debate.

II7 CONG. REC. 36,506 (1971).

167 I do not mean to assert that the public choice theory of interest group barter accurately describes the legislative process. Rather, I believe that the process involves the simultaneous concordance of many factors that may include political support by interest groups, broad political concern caused by some external triggering event, the visibility and breadth of a regulatory impact, and the positions in the legislature and administration of supporters of the proposed regulation. See John W. Kingdon, Agendas, Alternatives, and Public Policies 2I5-I8 (1984); Kay L. Schlozman \& John T. Tierney, Organized Interests and American 
The structure and decisionmaking processes of Congress also pose problems for judicial review. No clear test identifies when the legislative process passes civic republican muster. 168 Courts could not define such a test without inviting Congress to abuse it because Congress could easily formally respect the requirements laid down by the judiciary without truly deliberating. ${ }^{169}$ Judges would have to exercise great discretion in reviewing legislative hearings, committee reports, and debates to ascertain whether legislators truly considered all significant points of view and policy implications of the legislation. That the Congressional Record does not always reflect the legislative debate would hopelessly complicate such a task. ${ }^{170}$ Moreover, the courts could not easily overcome these problems because they have no authority to require Congress to change its procedures. Given the difficulties that courts have in using legislative history to inform themselves about the meaning of statutory language, I am not sanguine about their ability to use it to assess whether Congress engaged in a fully deliberative process. Such an assessment would depend critically on knowing how open-minded and honest legislators were when they considered a statute.

Judicial inquiry into Congress's adherence to civic republican norms would subject all congressional enactments to the threat of an irreversible veto. Any time that a court found that Congress had not satisfied civic republican criteria when passing legislation, it would invalidate the statute in question. Congress's only recourse would be to reenact the statute after more thorough deliberation, and even this might be futile. ${ }^{171} \mathrm{~A}$ court whose values conflicted with those expressed in a statute might repeatedly condemn the process by which Congress passed it, and hence effectively prevent Congress from enacting the provision. ${ }^{172}$

DEMOCRACY $3 \mathrm{I}_{4}-\mathrm{I} 7$ ( $\mathrm{x} 986$ ). The important point is that the legislative process is, by and large, not a rational, deliberative one (although it involves elements of rational decisionmaking), but rather one more dependent on happenstance.

168 Such a test could not easily focus on the outcome of legislation, because many of the same outcomes that could be justified as serving the public interest might also be characterized as benefiting particular interest groups. See Jonathan R. Macey, Transaction Costs and the Normative Elements of the Public Choice Model: An Application to Constitutional Theory, 74 VA. L. REv. $47 x, 472-73,472$ n.8 (r 988 ). Explicit use of legislative histories suffers from the possibly unavoidable problems previously noted. See Eben Moglen \& Richard J. Pierce, Jr., Sunstein's New Canons: Choosing the Fictions of Statutory Interpretation, 57 U. CHI. L. REv. I203, I215-I7 (1990); supra p. I545.

${ }^{169} \mathrm{Cf}$. ELY, supra note 28 , at $127-29$ (describing why a requirement that legislators articulate their motivations for voting for a statute would be unlikely to elicit the desired response).

${ }^{170}$ See supra note $\mathrm{I} 66$.

171 See CALABRESI, supra note 30 , at $163-66$.

172 This scenario raises the possibility that Congress, seeking to ensure that its legislation not be struck down, might create a constitutional crisis by attempting to deny the courts jurisdiction to review the statute's constitutionality. Whether Congress has the power to do this 
Permitting administrative agencies to make policy, subject to judicial review to ensure a civic republican process, avoids many of the problems with judicial review of congressional decisions. Judicial review of agency action would certainly require the courts to exercise great discretion in evaluating decisionmaking processes. But the agency explanation of its decision and its comprehensive decisionmaking record would allow judicial inquiry to focus on whether the agency permitted open discourse, addressed all significant concerns reflected in the record, and generally provided a persuasive explanation of why its decision furthers the public interest. 173

More significantly, judicial nullification of an agency decision would not cause problems as serious as those that result from the nullification of a legislative decision. Because agencies have greater flexibility to act quickly, they can more easily respond by reconsidering and, if appropriate, reinstating overturned decisions. Agencies often take such steps following judicial remand of agency actions found to be arbitrary and capricious. ${ }^{174}$ If a court were to overturn an agency determination that in fact reflected a consensus about public values, Congress could "overrule" the court by codifying the agency determination. ${ }^{175}$ That legislative action might not satisfy the civic republican

is a celebrated open question of constitutional law. See Lawrence G. Sager, The Supreme Court, I980 Term - Foreword: Constitutional Limitations on Congress' Authority to Regulate the Jurisdiction of the Federal Courts, 95 HARv. L. REv. I7, 68-74 (198I); William W. Van Alstyne, A Critical Guide to Ex Parte MICCardle, I5 ARIz. L. REV. 229, 264-66 (1973).

173 This is similar to what courts now do when they apply the "hard look" doctrine. See, e.g., Robertson v. Methow Valley Citizens Council, 490 U.S. 332, 350-52 (1989); Motor Vehicle Mfrs. Ass'n v. State Farm Mut. Auto. Ins. Co., 463 U.S. 29, 42-44 (1983). The civic republican standard would differ primarily in its expanded emphasis on judicial review of the agency's explanation that its decision serves the public interest and in its suspicion of courts' invoking a special authority to interpret statutes and thereby to second-guess well-reasoned agency policies. See infra notes I8I-I 82 and accompanying text.

174 See Peter H. Schuck \& E. Donald Elliott, Studying Administrative Law: A Methodology for, and Report on, New Empirical Research, 42 ADMIN. L. REv. 519, 534 (1990) (reporting that agencies did not adopt "major changes" in $60 \%$ of remands). In many cases, the courts affirm the same decision they initially reversed and remanded. See, e.g., Food Mktg. Inst. v. ICC, 587 F.2d I285, 1287-89, I295 (D.C. Cir. 1978); CPC Int'l, Inc. v. Train, 540 F.2d 1332, 1344-45 (Sth Cir. 1976), cert. denied, 430 U.S. 966 (r977); Portland Cement Ass'n v. Train, 513 F.2d 506, 507-09 (D.C. Cir.) (per curiam), cert. denied, 423 U.S. 1025 (1975).

${ }^{175}$ For example, Congress recently codified the Equal Employment Opportunity Commission guidelines, which interpret the Age Discrimination in Employment Act of 1967, 29 U.S.C.A. $\$ \$ 621-634$ (West 1985 \& Supp. 1991), to allow an employer to set benefits according to age only when consideration of age is cost-justified. See Older Workers Benefit Protection Act of I990, 29 U.S.C.A. $\$ 623(\mathrm{f})(2)(B)(i)$ (West Supp. r991). Congress explicitly overruled a contrary interpretation of the ADEA by the Supreme Court in Public Employees Retirement Sys. v. Betts 492 U.S. 158, I69-75 (1989). Cf. 42 U.S.C. $\$ 2239$ (a) (1988) (empowering the Nuclear Regulatory Commission to issue license amendments and interim licenses without prior hearings in a limited class of cases after the Court of Appeals for the D.C. Circuit had held in Sholly v. United States Nuclear Regulatory Comm'n, 65I F.2d 780 (D.C. Cir. 1980), vacated, 459 U.S. I 194 ( 1983 ), that the statute did not give the NRC that authority). 
criteria should cause less concern in this context because Congress would act after the deliberative administrative process and because such action would not often be required. The need for Congress to act would arise only if a court tried to impose its policy perspectives on the agency. Finally, in rare instances of repeated judicial resistance to an administratively implemented policy, Congress could restrict or even eliminate the courts' jurisdiction to review agency action. In essence, by delegating policymaking authority to a subordinate agency, Congress allows the courts to review agency decisionmaking to ensure that it comports with civic republican criteria without forfeiting the primacy that the Constitution grants to Congress as the body of duly elected representatives of the people.

My proposed civic republican understanding of the respective roles of agencies and courts might also deter a well-meaning court from illegitimately imposing its values on a regulatory scheme. Because judges see themselves as the ultimate interpreters of congressional meaning, they are apt subconsciously to read their values into regulatory statutes or accompanying legislative histories, which are often padded with conflicting gloss inserted by legislators hoping for a sympathetic judicial ear. ${ }^{176}$ Judges have continued to act in this manner despite the Supreme Court's admonition in Chevron U.S.A., Inc. v. Natural Resources Defense Council, Inc. ${ }^{177}$ that courts are to defer to agency interpretations of the statutes they administer unless the statute clearly contradicts the agency's ruling. ${ }^{178}$ After Chevron, if a reviewing court's values conflict with an agency's decision, the 'court might rely on its role as interpreter to overturn agency policy in either of two ways: the court might find that the statute imparts a clear meaning that renders the agency decision unlawful; ${ }^{179}$ alternatively, the court might determine that the legislative provisions require the consideration of factors that the agency failed to take into account, thereby rendering the agency's decision arbitrary and capricious. ${ }^{180}$

My civic republican model explicitly provides that the reviewing court's proper function is to ensure that the agency interpreted the

${ }^{176}$ See Angus MacIntyre, A Court Quietly Rewrote the Federal Pesticide Statute: How Prevalent is Judicial Statutory Revision?, 7 LAW \& PoL'y 249, 265-66 (1985).

${ }^{177} 467$ U.S. 837 ( 1984 ).

178 See id. at $842-43$. For examples of cases in which judges have skirted Chevron deference, see the cases cited below in notes $179-180$.

${ }^{179}$ See, e.g., K Mart Corp. v. Cartier, Inc., 486 U.S. 281, 293-94 (Ig88); INS v. CardozaFonseca, 480 U.S. 42r, 446-49 (1987); Public Citizen v. FTC, 869 F.2d 154I, 1553-56 (D.C. Cir. 1989). For a particularly egregious example of the use of statutory interpretation to overrule a sound agency policy decision, see Northern Natural Gas Co. v. FERC, 827 F.2d 779 (D.C. Cir. 1987) (en banc), in which the court interpreted the Natural Gas Act to prohibit FERC from setting rates that would have prevented a double recovery by gas companies of some of their costs. See id. at $784,792-93$.

${ }^{180}$ See, e.g., Independent U.S. Tanker Owners Comm. v. Dole, 809 F.2d 847, 852-54 (D.C. Cir.), cert. denied, 484 U.S. 8 Ig ( 1987 ). 
statute in a deliberative manner. The court should not interfere with the agency's use of its expertise and political awareness to reach a decision that the agency truly believes is good policy. Nonetheless, the court must make sure that the agency responded to all significant comments regarding the wisdom of its interpretation. The court must also make sure that the agency explained persuasively how its decision furthers the public interest. ${ }^{181}$ In other words, a court reviewing an agency interpretation must not measure the agency's action against the court's own reading of the statute, but instead must ensure that the agency followed the civic republican model of deliberative decisionmaking. ${ }^{182}$

To illustrate the benefit of my civic republican model of courtagency interaction, one could contrast it with the Supreme Court's use of statutory interpretation in the Benzene case. ${ }^{183}$ The case arose because the Secretary of Labor felt obligated by Section 6(b)(5) of the Occupational Safety and Health Act (OSHA) ${ }^{184}$ to set the industry standard for exposure to benzene at the lowest level achievable at a cost that would not "impair the viability of the industries regulated."185 Reacting to the potential cost of the proposed standard, the Supreme Court read Section $3(8)$ of the Act to require the Secretary first to find that benzene posed a significant risk to worker health; thus, the Court

181 Hence, my view of the respective roles of agencies and courts grants judges a more active role than does Chevron. My view is instead closer to the requirement that Christopher Edley proposes as part of his "sound governance" standard. See EDLEY, supra note 18, 231 ("[T]he court should communicate the reasons why the administrative record fails to instill confidence and provide clear guidance as to how the agency can assure the court that the administrative action is sound."). The republican notions of access, persuasive discourse and consensus, I believe, provide significant flesh for Edley's "sound governance" skeleton. But cf. Edley, supra note 18 , at 593 (critiquing civic republican conceptions as overly procedural, normatively empty, and utopian, and therefore concluding that civic republicanism is "an unstable way station for something else in the realm of theory").

182 For an opinion illustrating both the civic republican and pluralist approach, see Brae Corp. v. United States, 740 F.2d I023 (D.C. Cir. 1984) (per curiam), cert. denied, 47I U.S. I069 (I985). In Brae, the D.C. Circuit first demanded that the ICC prove its deregulation decision to be good policy, see id. at 1036-44, but in a later section of the opinion reverted to reading the legislative history of the Staggers Act as manifesting a legislative deal on behalf of small, regional railroads, see $i d$. at ro $48-49$.

183 Industrial Union Dep't, AFL-CIO v. American Petroleum Inst. (Benzene), 448 U.S. 607 (I980). To be sure, the Benzene case is pre-Chevron; nonetheless, it is useful in demonstrating a type of judicial activism that $I$ believe ought to be avoided.

18429 U.S.C. $\$ 655$ (b)(5) (1988).

185 Benzene, 448 U.S. at 613 (Stevens, J.) (plurality opinion). Section $6(\mathrm{~b})(5)$ provides: "The Secretary, in promulgating standards dealing with toxic materials or harmful physical agents under this subsection, shall set the standard which most adequately assures, to the extent feasible, on the basis of the best available evidence, that no employee will suffer material impairment of health . ..." 29 U.S.C. $\$ 655$ (b)(5) (Ig88). Because the Secretary found that there was a "causal connection between benzene and leukemia," he believed that no safe exposure level could be determined. Benzene, 448 U.S. at 613 . 
remanded the proceeding for such a determination. ${ }^{186}$ Unfortunately, the Court's interpretation ignored the fact that scientific evidence often will fail to resolve whether low levels of toxins pose a "significant" risk. ${ }^{187}$ Hence, the Benzene decision seriously hinders the regulation of toxic substances even in instances in which the Secretary could persuasively justify regulation. ${ }^{188}$ The Secretary's easiest (and perhaps only) solution to this problem would be to clothe her policy judgments in technical language and claim that the evidence supported the finding of significant risk. Because courts often are incapable, and certainly hesitant, to declare such conclusions erroneous, the decision would then escape exacting judicial review. ${ }^{189}$ This deferential review, however, encourages such evils as capture and sloppy decisionmaking.

The civic republican understanding would avoid these scenarios in which courts and agencies work at cross-purposes. An agency would not subject itself to reversal by admitting that it could not generate data implicitly required by a statute. Instead, the reviewing court would affirm the agency if the agency demonstrated that it interpreted the statutory requirements reasonably in light of scientific or economic limitations. This standard of review would encourage agency candor about its policy rationales - candor that would better persuade courts of the soundness of agency policies. 190 The review process would become a meaningful dialogue between court and agency in which the court stands in for the knowledgeable citizen that the agency must persuade to accept the regulatory policy.

2. Availability of Review by Politically Accountable Branches. Because courts are more insulated from the political pulse of the people than are agencies, judicial review alone is insufficient to ensure that agency policies remain true to the polity's consensus values. The place of administrative agencies in American constitutional government, however, also permits Congress and the President to review

186 See Benzene, 448 U.S. at $639-40$. Section $3(8)$ provided: "The term 'occupational safety and health standard' means a standard which requires conditions, or the adoption or use of one or more practices ... reasonably necessary or appropriate to provide safe or healthful employment and places of employment." 29 U.S.C. \$ 652(8) (1988).

${ }^{187}$ See Thomas O. McGarity, Substantive and Procedural Discretion in Administrative Resolution of Science Policy Questions: Regulating Carcinogens in EPA and OSHA, 67 GEo. L.J. 729, 740-49 (1979).

${ }^{188}$ See EDLEY, supra note 18 , at 90-9I, 91 n.42.

${ }^{189}$ See id. at 77 (suggesting that had OSHA subsequently relied on the same data and found a significant risk to health, the Court most likely would not have reversed again); see also Peter Huber, Safety and the Second Best: The Hazards of Public Risk Management in the Courts, 85 CoLUM. L. REv. 277, 33I-35 (I985) (arguing that courts are not as institutionally competent as agencies to manage public risk).

190 For an example of this type of judicial review, see Industrial Union Dep't, AFL-CIO v. Hodgson, 499 F.2d $467,475-76$ (D.C. Cir. I974). 
agency policies with an eye toward popularly held values. Although review by Congress and the President by no means ensures the fidelity of agency policy to a consensus of the common good, such review cabins agency decisionmaking so that it cannot stray too far from that consensus. 191

Congress's most direct reaction to an agency policy with which it disagrees is an explicit statutory override of an agency decision. Legislators typically override agency action, however, only when they realize that the agency decision poses a political problem, and when they are also able to agree on a solution that their constituencies support. Because overrides entail significant transaction costs, they occur infrequently. 192 In addition, overrides make legislators vulnerable to attack by interest groups whose immediate private interests the legislation threatens. ${ }^{193}$ Finally, such legislation must first pass through the subcommittees and committees responsible for the particular area of regulation. Of late, party influence and seniority have become less significant to the workings of the committee system. In the absence of these organizing forces, committees often cannot forge the coalitions necessary for legislative action. ${ }^{194}$ These factors contribute to an institutional inertia that undercuts the effectiveness of direct legislative reaction as a regular means of checking agency policymaking. Nevertheless, on several occasions, Congress has modified agency determinations that it found too extreme. 195

More often, Congress uses its power of the purse to keep agencies from adopting policies that stray from the desires of affected interest groups. ${ }^{196}$ In the scramble for legislative appropriations, an agency

191 Arthur Maass has suggested that Congress's role might more appropriately be viewed as checking executive policy-setting and implementation rather than leading the drive toward policy formation. See ARThur MaAss, Congress and the Common Good 8-r8 (1983).

192 See McCubbins, Noll \& Weingast, supra note 67, at 434; McCubbins \& Schwartz, supra note 73 , at $168-69$.

193 See Pierce, supra note 57 , at $1245-46$.

194 See Lawrence C. Dodd \& Bruce I. Oppenheimer, The House in Transition: Change and Consolidation, in Congress Reconsidered 31, 40-49 (Lawrence C. Dodd \& Bruce I. Oppenheimer eds., 2d ed. 1981); David E. Price, Congressional Committees in the Policy Process, in CONGRESS RECONSIDERED, supra, at I56, I56-70. But cf. MAASs, supra note I9I, at 8-I8 (asserting that Congress does play a crucial role in ensuring that legislation furthers the common good).

195 Perhaps the most noted recent example is Congress's reaction to the National Highway Traffic Safety Administration's (NHTSA) adoption, in 1972, of interim rules that required automobile manufacturers to install either passive restraints or ignition interlocks that prevented a driver from starting her car unless the seatbelt was fastened. See 49 C.F.R. \$ 1.5I (1973). Most manufacturers chose the less expensive interlock system, which proved to be extremely unpopular. In 1974, Congress passed the Motor Vehicle and Schoolbus Safety Amendments, which, among other things, rescinded the ignition interlock requirement. See Pub. L. No. 93492 , tit. I, \$ $102(\mathrm{~b})(\mathrm{I})$, S\$ Stat. 1470 , 4477 (1974) (codified at I5 U.S.C. \$ 14 Iob (I9\$8)).

196 See Peter L. Strauss, AN Introduction to Administratrve Justice in the United StaTes 55-56 (Ig8g). 
needs an advocate on Capitol Hill - especially one on the appropriations subcommittee that oversees the agency's regulatory program. ${ }^{197}$ Appropriations subcommittees frequently specify which programs are to receive funds. They also engage in non-statutory control over agency programs, for example, by requiring the agency to give the subcommittee advance notice of changes from the mutually understood allocation of appropriated funds. ${ }^{198}$ Although the White House's role in reviewing and coordinating budget requests from the various agencies complicates the influence of appropriations committees, evidence suggests that agency policies do respond to changes in the make-up and prevailing ideology of the agencies' appropriations committees. 199

Presidential review of agency policy is another means that brings the values of the electorate to bear on agency decisions. White House review, when properly structured, encourages deliberation and public interest oriented policymaking. The President answers to the entire electorate and thus has an incentive to oppose policies that hurt the general public more than they help particular interest groups. ${ }^{200}$ Three factors, however, temper the desirability of relying on presidential oversight of agency policy. First, the Office of Management and Budget, the White House arm for agency review, does not have the expertise to make ultimate regulatory decisions and may itself have an anti-regulatory bias. ${ }^{201}$ Second, even in national elections, the electoral process biases outcomes toward the status quo and the interests of powerful groups. ${ }^{202}$ Third, allowing any centralized institution under the direct control of one individual to dictate policy invites decisionmakers to rely on backroom discussions and, more generally, to subvert deliberative processes, even if that individual is electorally accountable. ${ }^{203}$

197 Traditionally, appropriations committees countered the pressures of the substantive oversight committees to support regulatory programs, but recently they too have become springboards that facilitate program advocates in making demands on the public fisc. See LANCE T. LELouP, The Fiscal Congress: Legislative Control of the Budget rog (ig8o); Allen Schick, Congress and Money: Budgeting, Spending and Taxing 415-40 (ig8o).

198 See MAASS, supra note $\mathrm{I} 9 \mathrm{I}$, at $\mathrm{r}_{38-40 .}$

199 See Weingast \& Moran, supra note 66, at $791-93$.

${ }^{200}$ See Peter L. Strauss \& Cass R. Sunstein, The Role of the President and OMB in Informal Rulemaking, 38 Admin. L. REv. I8I, 190 (1986); $c f$. Richard J. Pierce, Jr., The Role of Constitutional and Political Theory in Administrative Law, 64 TEx. L. REv. 469, 522-23 (r985) (arguing that, after Chevron, executive control over agency policymaking may result in greater political accountability).

201 See Strauss \& Sunstein, supra note 200 , at $19 \mathrm{I}-92$.

202 See supra note $\mathrm{r} 2 \mathrm{I}$.

203 There are those who allege that OMB has already used Executive Order 12,291, 3 C.F.R. $\$ 127$ (Ig8I), to subvert the regulatory process to serve surreptitiously powerful private interests. See, e.g., Jonathan Lash, Katherine Gilman \& David Sheridan, A Season of Spoils 23-25 (1984); Alan B. Morrison, OMB Interference with Agency Rulemaking: The Wrong Way to Write a Regulation, 99 HARv. L. REv. ro59, I062-63 (I986); Erik D. Olson, The Quiet Shift 
With some restructuring to address these problems, White House review of agency policy could help prevent agency capture and ideological parochialism. Executive Order I2,29I already requires each agency to submit cost-benefit analyses of major rules for detailed OMB review. 204 These analyses force the agency to expand its regulatory outlook beyond the factors it has traditionally considered paramount. ${ }^{205}$ In addition, Executive Order 12,498 mandates that an agency formulate a "regulatory program" before undertaking proceedings to implement its policies, ${ }^{206}$ which forces the agency to prioritize its policies and consider them in light of limited resources. ${ }^{207}$ Having agencies develop a regulatory agenda also facilitates White House coordination of various agencies' policies to ensure that they are consistent. ${ }^{208}$ Finally, detailed review by the White House communicates the administration's views on the values underlying a proposed policy, which, in turn, may reflect public sentiments on the issue. An agency might welcome such information in light of its responsibility to guide its regulatory ward through a labyrinth of technology, politics, and law.

The President's appointment power can also profoundly affect regulatory policy. ${ }^{209}$ The President should appoint agency members who share her perspective on matters that the agency will address. Assum-

of Power: Office of Management \& Budget Supervision of Environmental Protection Agency Rulemaking Under Executive Order 12,291, 4 VA. J. NAT. Resources L. 1, 55-57, 60-62 (1984).

204 See Exec. Order No. 12,291, 3 C.F.R. $\$ 127$ (1981), reprinted in 5 U.S.C. $\$ 601$ (1988).

${ }^{205}$ See Christopher C. DeMuth \& Douglas H. Ginsburg, White House Review of Agency Rulemaking, 99 HARV. L. REv. 1075, 1080-82 (Ig86). In order for OMB review to serve its deliberation-enhancing function legitimately, however, OMB should not have the authority to dictate outcomes to agencies either directly or by the threat of delays that are so great that they essentially undermine agency policy. See Strauss \& Sunstein, supra note 200, at I91-92 (discussing the dangers of OMB control). See generally Thomas O. McGarity, Presidential Control of Regulatory Agency Decisionmaking, 36 AM. U. L. REv. 443, 445 (1987) (arguing that the executive's role in controlling agency decisionmaking should be limited). Also, if OMB review is to contribute to the ultimate deliberation, the dialogue between the $O M B$ and the agency promulgating the rule must be part of the rulemaking record. Otherwise there will be no check on OMB's assertions, and White House influence will not be subject to knowledgeable political constraint. See Morrison, supra note 203, at 1067-68; Strauss \& Sunstein, supra note 200, at I $92-9.3$.

206 See Exec. Order No. 12,498. 3 C.F.R. $\$ 323$ (1985), reprinted in 5 U.S.C. $\$ 601$ (1988).

${ }^{207}$ See DeMuth \& Ginsburg, supra note 205, at 1087; Strauss \& Sunstein, supra note 200, at 187. Unfortunately, the impact of Executive Order 12,498 on the deliberative nature of agenda setting is limited because the public is not involved, and the agenda is not subject to any judicial scrutiny.

${ }^{203}$ See DeMuth \& Ginsburg, supra note 205, at 1082; Strauss \& Sunstein, supra note 200, at $189-90$.

209 See Strauss, supra note I96, at 63-68; Moe, supra note 157 , at I101; Terry M. Mae, Regulatory Performance and Presidential Administration, 26 AM. J. POL. SCI. 197, 200-or (1982). 
ing that this perspective was a factor in the President's election, the result would be an agency decisionmaker who harbored many of the relevant basic values and public aspirations of the national electorate.

None of the mechanisms for judicial and political oversight of agency action, taken alone, ensures that agencies will not pursue their own goals and agendas. Nonetheless, the mechanisms reinforce one another as means of limiting agency discretion. This intricate interplay seems to suggest that meaningful political constraints do exist, at least against agencies' pursuing goals far afield from those desired by the interest groups affected. ${ }^{210}$

\section{B. The Structure of the Bureaucracy}

In addition to administrative agencies' place in government, their internal structure also encourages deliberative decisionmaking aimed at furthering public rather than private values. At the core of almost every agency is a professional staff, chosen for its knowledge rather than for its political views or affiliations. ${ }^{211}$ The staff forms the base of a pyramid that has the ultimate decisionmakers, who are generally political appointees, at the apex. Although these appointees generate the agency's policy agenda, they depend on the bureaucrats below to evaluate the various alternatives for implementing broad policies. ${ }^{212}$ Career staff members derive their power primarily from their professional training and their relationships with interest group representatives who frequently control important information - in other words, from job-specific expertise. This expertise allows bureaucrats to exert significant influence on public policy even when their role is merely advisory. ${ }^{213}$ Although career staff rarely initiate consideration of general policies, the debate over policy alternatives often starts at lower levels and travels up the pyramid. This process has the potential to focus the debate on a professional understanding of the public interest rather than on accommodation of private interests.

210 See Moe, supra note 157 , at III4-15. Unfortunately, the political influence of Congress and the President has often translated into encouragement of agencies to pursue goals that civic republicanism considers illegitimate. Whether a republican model of judicial review together with other institutional constraints can channel political influence to check agencies from straying from the polity's notions of the public good remains uncertain.

${ }^{211}$ See Frederick C. Mosher, Democracy and the Public Service iri2-i3 (2d ed. I982); Samuel H. Beer, The Adoption of General Revenue Sharing: A Case Study in Public Sector Politics, 24 PUB. PoL. 127, 157-60 (1976); Frederick C. Mosher, Professions in Public Service, 38 Pub. Admin. Rev. 144, I45-46 (1978).

212 See Kingdon, supra note 167 , at $32-35$; B. GuY Peters, The Politics of BureauCRACY 137-4I (1978); William F. Pederson, Jr., Formal Records and Informal Rulemaking, 85 YALE L.J. 38, 52-55 (1975); Wallace S. Sayre, Dilemmas and Prospects of the Federal Government Service, Introduction to The Federal Government Service I, 2 (Wallace S. Sayre ed., 2 d ed. 1965).

${ }^{213}$ See KIngdon, supra note 167 , at 35-37; Francis E. Rourke, Bureaucracy, Politics, AND Public Policy i7-25 (2d ed. 1976). 
I. The Professional Rather than Political Nature of the Staff. Interest group representatives may suggest a policy alternative because the group has a private interest in seeing the change adopted, but non-political staff members evaluate proposals from their professional perspective. ${ }^{214}$ Staff bureaucrats focus on what they believe the public interest is and whether the suggested policy furthers it. Whether an agency staff member will forward a suggested alternative up the agency pyramid depends on the ability of interest group representatives to persuade her that, in her professional judgment, the alternative satisfies some public goal. ${ }^{215}$

Agencies are generally divided into staff offices that bring to a regulatory problem unique and perhaps parochial professional values and conceptions of the public interest. ${ }^{216}$ It is only through discussion among such offices that a policy emerges that can serve a more universal consensus of the common good. ${ }^{217}$ If, in fact, all staff members share a single professional background or even come from only a few professions, staff discussions might push agency policy toward a consensus shared by only part of society. If, however, agencies assign some staff members to interact with each different interest group and address its concerns - essentially to see that interest group as their clientele ${ }^{218}$ - it is more likely that intra-agency discourse would respond to all of the public's concerns.

The coal scrubbing controversy illustrates how this staff dynamic might work. The EPA Office of Air Quality represented the environmental interests who read the I977 amendments to the Clean Air Act to demand scrubbing. The Office of Planning represented general

214 See David Goetze, The Shaping of Environmental Attitudes in Air Pollution Control Agencies, 4I PUB. ADMIN. REv. 423, 423-24 (x981); Thomas O. McGarity, The Role of Regulatory Analysis in Regulatory Decisionmaking, in AdMINISTRATIVE CONFERENCE OF THE United States, Recommendations and Reports 107, 124-28 (i985); Charles Pruitt, People Doing IVhat They Do Best: The Professional Engineers and NHTSA, 39 PUB. ADMIN. Rev. $363,365-67$ (1979). The "professional" perspective of agency staff members might reflect the office they work for more than just their professional educational background. See Errol Meidinger, Regulatory Culture: A Theoretical Outline, 9 LAw \& PoL'Y 355, 373-74 (I987).

215 See MIcGarity, supra note 214 , at 126-27. McGarity, however, also contends that numerous institutional factors pressure technical staff members to promulgate some sort of regulations. See id.

216 See Charles T. Goodsell, The Case for Bureaucracy: A Public Administration PoLEMIC I3I-32 (2d ed. 1985); Carl J. Friedrich, Public Policy and the Nature of Administrative Responsibility, I PUB. POL. 3, 12-14 (1940).

217 See Friedrich, supra note 216 , at 22-24; McGarity, supra note 214 , at 139 .

${ }^{218}$ I have borrowed the term "clientele" from Joseph La Palombara, see JoSEPH LA PALOMBARA, INTEREST GROUPS IN ITALIAN POLITICS 262 (I964), to suggest that although an interest group depends on staff members for "representation" of its interests in the regulatory process, the staff members depend on the interest group to justify their institutional existence. $C f$. KRISLOV \& ROSENBLOOM, supra note 46, at 99 (describing this sort of symbiotic relationship between an interest group and an agency as one of agency clientele). 
economic interests. ${ }^{219}$ Although "turf battles" between these offices did play a distorting role, even at the staff level, 220 the interaction between the offices resulted in a proposed simple ceiling on sulphur emissions. The proposed ceiling would have reduced sulphur emissions more than the standard ultimately adopted (satisfying the environmentalists), and would have saved hundreds of millions of dollars (satisfying the economists). ${ }^{221}$ Unfortunately, backers of eastern coal intervened politically at the top levels of the agency and torpedoed this proposal. ${ }^{222}$

The coal scrubbing example also suggests that despite staff debate, the ultimate agency decisionmakers may not concern themselves with assessing the effects of a policy on the public interest as much as with satisfying powerful interest groups or the constituents of agency supporters in Congress. Courts, however, could review agency decisions to ensure that they were deliberative and demand that politicallyappointed agency members consider how a policy will affect what the staff and interest groups have identified as the public interest. With such a requirement, a decisionmaker faced with outsiders' arguments and staff analyses about whether a policy serves the public interest would either have to accept them or explain why they are not dispositive. Although judicial review would not entirely preclude an agency from setting policy based on private interest accommodation, it would at least ensure that the policy could be justified as a means of furthering some widely accepted notion of the common good. ${ }^{223}$

Some provisions of the Administrative Procedure Act (APA) ${ }^{224}$ and administrative law doctrine seem to recognize implicitly the important role that staff can play in influencing agency decisionmaking. In formal hearings, an Administrative Law Judge (ALJ) ${ }^{225}$ almost always presides and issues an initial or recommended decision. ${ }^{226}$ To the extent that ALJs exercise policymaking discretion, ${ }^{227}$ they tend to

219 See Ackerman \& Hassler, supra note 59, at $1536-37$.

220 See id. at $1539-40$.

221 See id. at 1545 .

222 See id. at $1548-49$.

223 See Sunstein, supra note 10, at 63-64; cf. EDLEY, supra note 18, at I94 (arguing that hard look review limits an agency's use of politics to decide between "otherwise reasonable alternative constructions of the evidence").

2245 U.S.C. $\$ \$ 551-559,701-706$ (1 988$)$.

225 See id. \$ 556(b)(3).

${ }^{226}$ See id. $\$ 557$ (b). The APA requires a preliminary ALJ decision in every formal proceeding over which an ALJ presides, except for the narrow exception when "the agency finds on the record that due and timely execution of its functions imperatively and unavoidably . . requires [bypassing the ALJ's decision]." Id. $\$ 557(\mathrm{~b})(2)$.

227 Many ALJs today preside over the enormous quantity of Social Security cases, which primarily involve taking evidence and making findings of fact; the sheer volume of such cases implies that the impact of ALJs on agency policy will be neither systemic nor significant. The 
justify their policy choices by invoking public-interest oriented statutory or regulatory purposes and established agency policies. Although the initial or recommended decisions may have political overtones in terms of who "wins" and "loses," the outcomes generally are not driven by explicit political concerns. ${ }^{228}$ Of course, an ALJ's tentative resoIution of a policy issue may not withstand review by the agency, which makes its ultimate decision de novo and thus ostensibly need not heed the initial or recommended decision. ${ }^{229}$ In practice, however, the parties must make their arguments to the agency members "on exception" from the ALJ's decision, which therefore defines the parameters by which the agency will ultimately evaluate the policy at issue. ${ }^{230}$ Moreover, the Supreme Court has made it clear that the agency must explicitly address the ALJ's findings and rationales if it rejects the recommended decision. ${ }^{231}$

Unfortunately, this limited use of staff and ALJs to remove issues from immediate political pressures does not ensure that the agency deliberates about the public interest before it adopts a new policy. Staff and ALJs play this role only in formal proceedings, which, like judicial hearings, are not conducive to deliberative dialogue and tend to restrict interest group access. ${ }^{232}$ There are no analogous APA provisions or administrative law doctrines that recognize staff involvement in the formulation and analysis of agency policy in informal rulemakings, the paradigmatic process for agency policy-setting, or in the more informal interactions that occur before official proceedings commence. ${ }^{233}$ More troubling, the push for many agency policies comes from elected officials and appointed agency heads, ${ }^{234}$ whom interest groups are more likely to influence. Policy considerations driven from the top down send staff members a message not to filter out purely political arguments.

role of ALJs in other regulatory agencies, however, often does involve preliminary determination of important policy issues.

${ }^{228}$ ALJs' decisions are political to the extent that they take into account legitimate agency policies that have a bearing on their cases. However, the APA insulates ALJs from direct influence by agency heads and the rest of the agency staff with respect to particular decisions. See 5 U.S.C. $\$ 554$ (d) (1988). Reagan-era attempts to pressure ALIs directly to deny social security benefits with greater frequency are troubling precisely because these attempts suggest that ALJs may react to direct political influence. See Victor W. Palmer \& Edwin S. Bernstein, Establishing Federal Administrative Law Judges as an Independent Corps: The Hefin Bill, 6 W. NEw ENG. L. REv. 673, 694 (1984).

${ }^{229} \mathrm{See} 5$ U.S.C. $\$ 557$ (b) (1988).

230 See id. $\$ 557$.

231 See Universal Camera Corp. v. NLRB, 340 U.S. 474, 495-96 (195I).

232 See supra notes $158-160$ and accompanying text.

${ }^{233}$ For a rare example of a case in which a court explicitly recognized that staff experience may significantly enlighten policy choices, see Judge Breyer's opinion in Donovan v. A. Amorello \& Sons, Inc., 76r F.2d 6r, 66 (Ist Cir. 1985).

${ }^{234}$ See KINGDoN, supra note 167 , at 23-33. 
The problem of agencies ignoring their staffs' professional perspective is surmountable. It is not a problem inherent in the structure of the agency but rather one that results from jettisoning valuable attributes of that structure that might discourage factional decisionmaking. For example, one could address the problem of agency decisionmaking from the top down by amending the APA to give potentially affected groups and agency staff a greater role in initial policy formulation. ${ }^{235}$ Additionally, Congress and the President could require agencies to announce publicly and then to justify a policy-setting agenda. ${ }^{236}$

More troublesome is the propensity of agencies to marginalize the values of those outside the political mainstream. This problem is intractable in large part because neither the professional ethic of the staff nor the political ethic of agency heads is likely to incorporate these values. ${ }^{237}$ It is not clear, however, that the alternatives legislative or judicial definition and implementation of policy - would respect non-conforming values any more than the administrative state. Although I see no institutional method of alleviating this problem entirely, reviewing courts could demand that agencies explicitly address all relevant arguments made by fringe groups. This requirement would at least trigger a sensitivity to non-mainstream perspectives at two levels - at the agency upon initial consideration and the courts upon review.

235 Congress recently took a big step in this direction when it adopted the Negotiated Rulemaking Act of I990, Pub. L. No. IoI-648, § $3($ a), IO4 Stat. $4969,4970-77$ (codified at 5 U.S.C.A. \$\$ 58I-59o (West Supp. I99I)). Negotiated rulemaking brings the major affected interest groups together before policy is formulated to try to work out regulation that benefits all interests. For a description of negotiated rulemaking, see Harter, supra note 160 , at 28-3x;

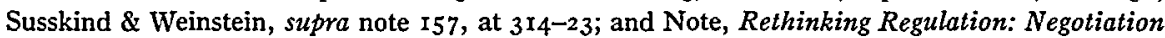
as an Alterative to Traditional Rulemaking, 94 HARV. L. REV. 1871, 1874-80 (1981). This approach, however, is not problem-free; it often does not result in any agreement on regulations, might ultimately encourage intransigence of the agency during the rulemaking proceeding with respect to changes in a negotiated proposed rule, and therefore might deprive non-mainstream interest groups of an equal opportunity to influence policy.

${ }^{236}$ Creating some public process by which agencies formulate agendas would improve judicial monitoring of agency failure to further the public interest by giving judges some record for reviewing petitions challenging an agency's refusal to adopt a rule or policy. $C f$. Natural Resources Defense Council, Inc. v. SEC, 606 F.2d ro3I, I046 (D.C. Cir. I979) ("Judicial review of agency decisions not to adopt rules would help ensure that the agency gives due consideration to citizen participation, and in this sense might actually enhance the agency's effectiveness in furthering the public interest."); Richard B. Stewart \& Cass R. Sunstein, Public Programs and Private Rights, 95 HARV. L. REV. II93, 1267-89 (1982) (discussing judicially-created initiation rights and noting both their benefits and the enforcement problems they create).

${ }^{237}$ By most measures, the public service accurately mirrors the general population in both composition and policy attitudes. See Goodsell, supra note 216 , at 82-88. There are, however, a few glaring distortions in the representativeness of the public bureaucracy: blacks and women are underrepresented in upper levels (that is, policy influencing levels), see id. at 85 , and the bureaucracy on the whole is skewed toward middle class values, see KRISLOV \& ROSENBLOOM, supra note 46 , at 59 . 
2. The Pyramidal Structure of Agencies. - The pyramidal structure of agencies dovetails with the professional ethic of their staffs to foster interest group access, deliberation, and feedback. The presence of many staff members at the career level and the organization of staff into divisions with particular responsibilities permit interest group representatives to identify and communicate with public officials sympathetic to their perspectives. Interest group representatives and staff can discuss potential agency policies and the staff's tendency is to focus the discussion away from pure political concerns. ${ }^{238}$ Agency staff also can carry credible interest group concerns to the upper echelons of the agency and can carry agency responses back to the interest groups.

Again, I am not arguing that staff members adequately perform these soundingboard and conduit functions in most agencies today. Only focused interest groups that participate repeatedly in agency affairs learn that staff can play these valuable roles and recognize which staff members are best at it. Hence, these "insider" interest groups derive an unfair advantage because of their relationships with career-level staff. The most powerful interest groups often can even appeal directly to agency members or their close advisors. To approximate civic republican ideals more effectively, Congress should discourage these "sweetheart" relationships, perhaps by requiring agencies to document publicly even informal contact between agency officials and interest group representatives. In addition, the government should counter the disincentives that deter unfocused interest groups from participating in agency proceedings. These disincentives, which are created by the costs of participation and are exacerbated by free rider problems, justify government reimbursement of interest groups that succeed in altering agency policy. ${ }^{239}$

\section{Agency Policymaking Procedures}

The availability of agency procedures that facilitate access and public interest oriented discourse provides a third basis for my optimism about the ability of the administrative state to implement a civic

${ }^{238}$ See supra notes $214-218$ and accompanying text.

${ }^{239}$ Cf. Bernard S. Black, Shareholder Passivity Reexamined, 89 Mich. L. REV. 520, 580 (1990) (suggesting cost reduction and a fee award scheme for shareholders who successfully challenge corporate policy as means of enhancing shareholder participation in corporate governance). With certain exceptions, the Equal Access to Justice Act, 5 U.S.C. $\$ 504$ (I988), already provides an award of fees and expenses to private litigants who prevail in an agency adjudication. See id. $\$ 504(\mathrm{a})(\mathrm{r})$. This statute, however, is tailored to encourage private parties to vindicate their rights and to curb unreasonable exercises of government authority, not to mandate a more deliberative decisionmaking process. See Equal Access to Justice Act, Pub. L. No. 96$48 \mathrm{I}, \$_{202,} 94$ Stat. 2321 , 2325 (1980) (findings and purposes); H.R. REP. No. 14I8, 96th Cong., 2d Sess. I2 (Ig8o); Commissioner, INS v. Jean, I Io S. Ct. 2316, 232 I (I990). 
republican model of policymaking. In particular, the paradigmatic process for agency formulation of policy - informal rulemaking - is specifically geared to advance the requirements of civic republican theory. Informal rulemaking requires public notice sufficient to inform interest groups that the agency is considering a policy that might affect them. ${ }^{240}$ Any group that keeps abreast of developments at a particular agency or regularly reviews the Federal Register learns of the agency's commencement of an informal rulemaking proceeding. Comment procedures provide relatively easy access to the discourse among interest groups and the dialogue between those groups and decisionmakers.

The availability of rulemaking procedures, however, fuels my optimism only to a limited extent. The actual procedures that agencies use may discourage them from taking advantage of the discourse that notice and comment rulemaking can produce. The most pervasive problem with informal rulemaking is that an agency usually investigates the issues and has its staff perform preliminary analyses of regulatory options before it initiates a rulemaking proceeding. ${ }^{241} \mathrm{Be}$ cause this preliminary work is done without organized public input, the interest groups not involved in the preliminary stages may feel excluded from the rulemaking process and assume an antagonistic attitude upon a rule's proposal. 242 Moreover, if only "insider" interest groups have input into the preliminary stages of a rule's development, the rule itself is apt to favor their private interests. ${ }^{243}$ An agency can exacerbate these problems by withholding data and staff analyses that may have prompted it to initiate the rulemaking proceeding or to formulate the proposed rule as it did. Furthermore, informal rulemaking proceedings do not mandate that parties have an opportunity to respond to comments filed by other groups. The only chance to respond may be through a petition for reconsideration or for judicial review, and by that time, the agency and "insider" groups are likely to have crystallized their positions and hence to view other parties as adversaries. As a result, informal rulemaking often does not generate

${ }^{240}$ See Administrative Procedure Act, 5 U.S.C. $\$ 553$ (b) (1988); Florida Power \& Light Co. v. United States, 846 F.2d 765, 77 I (D.C. Cir. I988), cert. denied, 490 U.S. I045 (I989); Natural Resources Defense Council, Inc. v. EPA, 824 F.2d I258, I283 (Ist Cir. 1987).

241 See Pederson, supra note 212 , at 5I-59.

242 Robert Reich has hypothesized that much of the antagonism begins in the informal preliminary stages because interest group representatives, especially those working for industry, are lawyers concerned about preserving their positions and informational advantages for future proceedings. See Robert B. Reich, Regulation by Confrontation or Negotiation?, 59 HaRv. Bus. REv., May-June I981, at 82, 86-91.

${ }^{243}$ See Roy A. Schotland, After 25 Years: We Come to Praise the APA and Not to Bury It, 24 ADMIN. L. REv. 26r, 266-67 (1972); Stewart, supra note 9, at 1775. 
true discourse but rather encourages participants to pursue their private interests single-mindedly. 244

Despite the flaws in current rulemaking practices, Congress and the courts can act to overcome the institutional problems outlined above. In several cases, courts have struck down regulations promulgated when the agency did not first disclose the scientific data upon which it relied, because the regulations ignored meaningful industry comments. ${ }^{245}$ In other cases, judges have added an opportunity for additional rounds of comments after the agency has changed its position. ${ }^{246}$ Both types of court action help ensure that rulemaking proceedings fulfill their potential as vehicles for civic republican deliberation. Requirements that agencies reveal the value choices inherent in the selection of one rule over an alternative and that they encourage representatives of various interests to discuss fundamental issues would also further civic republican aims. ${ }^{247}$

Additional problems arise, however, because agencies frequently set policy outside the rulemaking paradigm - either in non-binding policy statements or as part of fact-specific adjudications. I have already explained how formal adjudicatory proceedings limit access and discourage deliberation. ${ }^{248}$ Setting policy by informal adjudication or by issuing general policy statements only magnifies these problems.

The Administrative Procedure Act grants agencies virtually complete discretion over the procedures they use to conduct informal adjudication and to issue general statements of policy. ${ }^{249}$ In both contexts, agencies obtain their data and views about policies they might adopt from selective sources. Only "active players" who work

244 See STRAUSS, supra note I96, at I69-7 I; Harter, supra note I6o, at 22.

245 See, e.g., United States v. Nova Scotia Food Prods. Corp., 568 F.2d 240, 253 (2d Cir. 1977).

${ }^{246}$ See, e.g., Portland Cement Ass'n v. Ruckleshaus, 486 F.2d 375, 394-95 (D.C. Cir. I973), cert. denied, 417 U.S. 92 I (1974). The Supreme Court's holding that courts may not add to APA procedures, see Vermont Yankee Nuclear Power Corp. v. Natural Resources Defense Council, Inc., 435 U.S. 519, 523-25 (1978), has discouraged lower courts from adding procedural requirements. See generally Alfred S. Neely, IV, Vermont Yankee Nuclear Power Corp. v. Natural Resources Defense Council, Inc.: Response and Reaction in the Federal Judiciary, I4 U. BALT. L. REV. 256, 264-307 (1985) (summarizing the response to Vermont Yankee by the lower courts). Lower courts, however, may still insist on a deliberative process by tying the requirements to the basic provisions of the APA, such as the requirement of "meaningful notice," see, e.g., Corrosion Proof Fittings v. EPA, 947 F.2d 1201, 1212 (5th Cir. 1991), or by premising their opinions on substantive inadequacies in agencies' explanation of their decisions, see, e.g., Independent U.S. Tanker Owners Comm. v. Lewis, 690 F.2d 908, 926-3I (D.C. Cir. 1982).

${ }^{247} \mathrm{Cf}$. Reich, supra note 13 , at $\mathrm{I} 638-40$ (suggesting that administrative agencies should foster national debate on value-laden issues).

${ }^{248}$ See supra notes $158-160$ and accompanying text.

${ }^{249}$ See 5 U.S.C. $\$ 553(\mathrm{~b})(\mathrm{A})$ (Ig88). 
closely with agency personnel have any chance to address the issues raised by the adoption of these policies. No requirements of an open record or public discussion operate to constrain pure political influence or an agency's pursuit of a private agenda. ${ }^{250}$ For statements of policy, the usual justification for the absence of any required procedures is the non-binding nature of such statements. ${ }^{251}$ From a civic republican perspective, however, this justification is inadequate. Subsequent agency adjudicatory proceedings are adversarial and hence probably will not cure the lack of opportunities for access and deliberation. ${ }^{252}$ The adversarial nature of subsequent proceedings will be aggravated by the fact that the agency has already committed itself to a position and may be reluctant to consider seriously arguments to the contrary.

As the above discussion illustrates, agency policy-setting has the potential to advance civic republican goals. But the same attributes that suggest that agencies can provide civic republican benefits their place in American constitutional democracy, their structure, and the decisionmaking processes that they use - may also permit and even facilitate domination of the polity by either the decisionmakers themselves or by private interest groups that have co-opted the system to serve their private preferences. In other words, heavy reliance on the administrative state to set policy creates a substantial risk of a government that not only fails to deliver the promises of civic republicanism, but stumbles into many of its pitfalls as well.

\section{Avoiding the Pitfalls of Crvic Republicanism}

The potential pitfalls inherent in a civic republican government fall into four distinct categories. The first two categories encompass pitfalls that result from an inability to ensure that decisionmakers act

250 Courts, however, have construed APA review under the arbitrary and capricious standard to mandate that the agency explain the bases of its challenged decisions, even those made through informal proceedings. See Citizens to Preserve Overton Park, Inc. v. Volpe, 40r U.S. 402, 420 (1971). Courts have also adopted the requirement of an agency record in informal proceedings, which includes the material the agency considered in reaching its decision. See id. at 4 rg. In addition, the Freedom of Information Act, 5 U.S.C. $\$ 552$ (Supp. I9gI), and the Government in the Sunshine Act, 5 U.S.C. $\$ 552$ b (1988), enable private citizens to obtain information about agencies' informal communications. See STRAuss, supra note 196, at 16364. These doctrines and statutes go a long way toward discouraging decisions that purely enhance private interests.

251 An entity may challenge a statement of policy when the agency applies it in a particular adjudicatory proceeding. See American Hosp. Ass'n v Bowen, 834 F.2d I037, 1046-47 (D.C. Cir. I987); Jean v. Nelson, 7 I I F.2d 1455, 148I-82 (I Ith Cir. I983), rev'd on other grounds, 727 F.2d 957 (I Ith Cir. I984) (en banc), aff'd, 472 U.S. 846 (I985).

252 See supra p. 1562. 
with the public interest rather than personal gain in mind. ${ }^{253}$ In the absence of oversight, regulators may engage in conduct aimed directly at fulfilling their private preferences. If, however, a powerful special interest group monitors the regulator, that group might offer inducements that entice the regulator to serve its private interests. This is the classic capture scenario. ${ }^{254}$ The second two categories include pitfalls that can result even if regulators act with the public interest in mind, because the process of reaching consensus may go awry. Even the publicly minded regulator may enjoy sufficient freedom from oversight to impose unintentionally her unique conception of the public good on the polity. Alternatively, if majoritarian institutions closely monitor the regulator, they might force her to adopt laws that embody only the dominant culture's background and values. I believe, however, that with properly structured constraints on agency discretion, the administrative state can avoid the pitfalls of civic republicanism.

\section{A. Regulation that Promotes Decisionmakers' Private Interests}

Unless other government institutions or private interest groups impose constraints, regulators will often pursue their own private interests. This pursuit partially explains the failure of the New Deal agency model, which naively assumed that regulators would diligently implement statutory goals. History has shown that all too often regulators shirk their responsibilities; they prefer the leisure and security that accompanies the continuation of what is routine. ${ }^{255}$

253 Personal gains include any personal utility the regulator derives from continued officeholding such as power, prestige, convenience, and security, as well as pecuniary benefits. See ANTHONY DOWNS, INSIDE BUREAUCRACY 84-85 ( 1967 ).

254 Marver Bernstein provided the classic explanation of capture in his description of the life cycle of an agency. See BERNSTEIN, supra note 31, at 86-90, 155-60. More recent economic theory also predicts that industries will try to capture agencies. See, e.g., Stigler, supra note 122 , at 5-6.

255 See Bernstein, supra note 31 , at 88-92; Downs, supra note 253 , at $18-20$, 96-100. It should be remembered, however, that failure to take the initiative is a malady that befalls legislators as well as agency decisionmakers. An elected representative who actively promotes a public policy runs the risk of losing some voter support, usually without any meaningful potential for gaining votes. See MorRis Fiorina, Representatrves, Roll Calls, and CoNStituencies 36-38 (i974); Paul J. Quirk, Industry Influence in Federal Regulatory AGENCIES 88-89 (I98I). Incumbent legislators generally enjoy greater name recognition, resources for publicity, and ability to help their constituents deal with government "red tape" than their challengers, which gives them an inherent electoral advantage. See Fiorina, supra note 121, at 98-101 (arguing that increases in the retention rates of incumbent legislators are due primarily to their ability to perform direct services for their constituents). Thus the safest strategy for incumbents single-mindedly seeking reelection may be to obfuscate their positions to avoid the backlash of disgruntled voters who may represent the only true threat to their reelection. 
Hence, civic republican theory must address the phenomenon of agency lethargy. Two interrelated approaches can help solve the problem of agency shirking. First, requiring agencies to state and justify their agendas would focus attention on agencies that do not take sufficient steps to meet their statutory mandates. At present, agencies tend to set their agendas in political rather than in more deliberative forums. ${ }^{256}$ Media coverage of announced agendas could generate political pressure on Congress and the President to remedy extreme cases of shirking. If the history of the administrative state teaches us anything, however, it is that private interest groups are more dedicated and probably more efficient monitors of agency actions than are government officials. Legislators and the President may prefer the relative stability and lack of controversy that often accompany agency inaction. Hence, the formal involvement of the public in setting an agency's agenda might be needed to goad agency officials into explicitly considering long-term regulatory goals. To give teeth to private monitors, courts could consider the announced agenda and the record leading to its adoption when reviewing agency refusals to initiate rulemakings or to enforce statutory provisions. ${ }^{257}$

In addition to shirking, officials' self-interest also creates incentives for them to augment their regulatory authority. Greater power allows regulators to increase monopoly rents, ${ }^{258}$ which they can then trade to interest groups in return for personal benefits such as future jobs or freedom from criticism. ${ }^{259}$ Regulators may also derive a direct psychic benefit from the power they exercise. 260 Thus, the potential for regulators to pursue their self-interest suggests that Congress should limit agencies' discretion to expand their regulatory power;

256 See KINGDON, supra note 167 , at 47 .

257 The adoption of an agency agenda should be treated as a policy statement that is not binding on the agency and hence not directly reviewable in court. The call for regulatory measures often arises due to external "focusing events" that occur by happenstance. See id. at 99-103. Therefore, holding an agency to the letter of an announced agenda could seriously hamper its ability to respond expediently to such events. In addition, direct judicial review would also threaten to involve the courts in agency management of resources, a task for which they are not well suited. See Stewart \& Sunstein, supra note 236, at 1282-83. By contrast, the use of the agenda setting proceeding as part of the record in judicial review of particular cases of agency inaction would facilitate a task that the courts currently perform hesitantly and too deferentially. See, e.g., Williams Natural Gas Co. v. FERC, 872 F.2d 438, $443-44$ (D.C. Cir. I989); WWHT, Inc. v. FCC, 656 F.2d 807, 8Ig-2o (D.C. Cir. Ig8I).

258 See Levine \& Forrence, supra note 123, at 169-70; Roger G. Noll, The Behavior of Regulatory Agencies, 29 REv. Soc. ECoN. I5, I5-I9 (I97 I); supra note 122 and accompanying text.

259 This is the theoretical basis for much of the public choice literature on agency capture, which I discuss in section IV.B. In this section, I briefly discuss this problem from the perspective of the regulator's self-interest rather than the interests of the regulated entity or other private interest groups.

260 See Downs, supra note 253 , at 84 . 
likewise, reviewing courts should not defer to an agency's statutory interpretation that increases the bounds of the agency's jurisdiction. ${ }^{261}$

\section{B. Agency Capture by Private Interest Groups}

The second potential pitfall of civic republicanism stems from the ability of an ostensibly regulated industry to influence government policy. According to the capture hypothesis, instead of providing meaningful input into deliberation about the public interest, industry representatives co-opt governmental regulatory power in order to satisfy their private desires. ${ }^{262}$ Regulated entities are well organized and generally well funded, and they often have strong interests at stake, which they do not share with the polity as a whole. These entities have much to gain by ensuring that they have control over government decisionmakers and that the decisionmakers whom they do control remain in office.

Traditional theory posits that interest groups face a much easier task if they set out to capture an agency than if they try to capture Congress. ${ }^{263}$ Often agency staff members have worked in the regulated industry and thus share the industry's perspective and values. ${ }^{264}$ Many agency staff members expect to work eventually for some regulated entity, at which time they will cash in on the inside knowledge and experience gained in relatively low paying government positions. Not wanting to jeopardize this opportunity, they hesitate to criticize harshly industry proposals and arguments. ${ }^{265}$ In addition, well-or-

261 Sunstein argues against deferring to agency interpretations of statutes unless such interpretations are explicitly authorized by Congress, under the principle that "foxes should not guard henhouses." SunsteIN, supra note I3, at I43-44. I agree with the principle but do not believe that most questions that require filling the gaps in ambiguous regulatory statutes significantly enhance agency powers. Jurisdictional questions, however, which involve whether the agency has the authority even to consider a policy in the first place, directly involve the extent of agency power. Therefore, courts should not defer to agency interpretations of jurisdictional provisions.

262 For a comprehensive discussion and evaluation of both the general idea of capture and the particular mechanisms by which it can come about, see QuIRK, supra note 255.

${ }^{263}$ Classic capture theorists assert that commissions that regulate a single industry are particularly susceptible, because these commissions depend on their industry counterparts to supply information necessary for effective regulation. See BERNSTEIN, supra note 31 , at $92-93$; Roger G. Noll, The Sacial Costs of Government Intervention, in THE BusINESS-GoverNMENT Relation: A Reassessment 56, 6I (Neil H. Jacoby ed., I974). Public choice theorists contend that capture can occur whenever an agency sees itself as serving a single group and that group has well-defined and focused interests. See Levine \& Forrence, supra note 123, at 169-70. Thus, even agencies whose regulatory authority cuts across industries can be captured - for instance, by a "public interest" group such as environmentalists or by a group such as organized labor that exerts influence across industries.

264 See QUIRK, supra note 255, at 19-20.

265 See id. at i9; Roger G. Noll, Merton J. Peck \& John J. McGowan, Econonic Aspects of Television Regulation $123-24$ (I973). 
ganized and well-funded regulated entities can also affect the immediate interests of agency staff members and heads; if these individuals do not accede to the demands of the regulated entity, they may find themselves embroiled in numerous adversarial proceedings, which reduce their ability to address other regulatory matters. ${ }^{266}$ Finally, it is easier to influence the few agency members who are responsible for making ultimate decisions than the hundreds of legislators needed to pass regulatory bills.

This accepted learning, however, may grossly overstate the susceptibility of agencies to capture relative to the susceptibility of Congress. An agency organized into distinct offices, each filled by professionals from different backgrounds who communicate with a different clientele, can avoid decisions that reflect a single industry's perspective. Consideration and discussion of regulatory policy by various departments make that policy less likely to reflect the views of one group of agency staff members who may be imbued with a particular industry's values. ${ }^{267}$ Staff members' understanding that their goal should be to implement the public interest may further enhance their tendency to try to reach a universal accord on policy. This understanding may even encourage selection of public servants predisposed to the use of persuasive discourse. ${ }^{268}$

The perception that employment opportunities within a regulated industry may depend on favoritism by career staff members does create some potential for agency capture, ${ }^{269}$ but this potential is unlikely to be significant. First, because conflict of interest statutes outlaw exchanges of influence for future jobs, ${ }^{270}$ staff members cannot solicit promises of future employment in exchange for favorable industry treatment. To provide favorable treatment without a guarantee of future employment is a risky strategy; the staff member may jeopardize her career in the agency. ${ }^{271}$ Second, although some staff members perceive that pro-industry bias helps secure a subsequent industry job, many staff members do not perceive this. ${ }^{272}$ Frequently, the regulated entity hires individuals who will best promote its interests after they are hired. Thus, it will prefer a staff member who knows

266 See QUIRK, supra note 255 , at 1 7-18; Noll, supra note 258 , at 17-19.

267 See GoODSELL, supra note 216 , at I32; QUIRK, supra note 255 , at 92 ("[T] nature of a large part of agency policy making not only limits the centrifugal effect of attitudinal dissensus, it makes diversity of viewpoints positively functional.").

268 See GoODSELL, supra note 216, at 90-9I; Quirk, supra note 255, at 9I-92.

${ }^{269}$ See QuiRK, supra note 255 , at $x 63-64$.

270 See I8 U.S.C. $\$ 203$ (I988). In addition, no employee may represent a private entity before an agency in matters he worked on or supervised in his former official capacity, see id. $\$ 207(a)$, and high level agency staff and agency members may not appear before the agency as a representative of a private entity within one year after leaving the agency, see id. $\$ 207$ (c).

271 See QuIRK, supra note 255 , at 166-67.

272 See id. at $163-64$. 
how the agency operates even if she has previously worked to the entity's detriment. ${ }^{273}$ Third, structuring agencies to involve various interest groups and staff offices in the policy debate and requiring agencies to support their decisions with persuasive reasons would minimize the likelihood that capture of some staff members will cause the agency to adopt (and to defend successfully on review) a proindustry policy.

Finally, focusing on the difference between the number of members of Congress who vote on legislation and the number of agency members who vote on regulation creates misperceptions about the relative ability of special interest groups to capture agencies. Although all members of Congress have a vote, their choices are dictated to a large extent by the actions of smaller subcommittees and powerful committee chairs. ${ }^{274}$ Furthermore, committee staffs play an important role in legislative decisionmaking, and inducements to favor industry can be just as great for congressional staff members as for agency personnel. In fact, legislative staff may be more prone to capture because their work generally occurs behind closed doors, unlike all but the most informal aspects of agency decisionmaking. ${ }^{275}$ Finally, special interest groups might enjoy greater influence over legislators than agency members because legislators are directly elected and hence more vulnerable to public sentiments that funded interest groups can generate.

The savings and loans crisis underscores that agency capture may stem from the interaction between legislative and administrative vulnerability to interest group influence. ${ }^{276}$ Troubled savings and loans found it difficult to induce enough career regulators to act on their behalf, but they were able to sway legislators on the oversight and budget committees and appropriate agency heads. The crisis thus demonstrates that even well-meaning agency members respond to the wishes of legislators who control the agency's authority and budget. By focusing lobbying efforts on legislators, special interest groups may be able to capture agencies by threatening agency members' power and reputation. The crucial point is that special interest groups and regulated industries often use their influence over powerful members of Congress to affect regulatory policy. ${ }^{277}$

${ }^{273}$ See id. at $171-72$.

274 See Price, supra note 194 , at 158 ; supra notes $161-167$, I96-199 and accompanying text.

275 See Mashaw, supra note 153 , at $98-99$.

${ }^{276}$ For a general discussion of the causes of the savings and loan crisis, see Symposium, Savings and Loan Crisis: Lessons and a Look Ahead, 2 Stan. L. \& PoL'Y Rev. 2 I (19go).

277 For example, there is general agreement that statutory enactments that were intended to "aid" savings and loans in the late 19705 and early 1980s, coupled with direct congressional influence on the Federal Home Loan Bank Board (FHLBB), fueled the savings and loan crisis. See Edwin J. Gray, Warnings Ignored: The Politics of the Crisis, 2 Stan. L. \& Pol'y Rev. I38, I42-43 (I990); Thomas Romer \& Barry R. Weingast, Congress: The Genesis of the Thrift 
The foregoing discussion illustrates why civic republicanism cannot rely on congressional oversight alone to prevent capture. Some literature addressing the problem that capture poses for a pluralistic understanding of administrative discretion suggests that greater reliance on presidential oversight would discourage capture. ${ }^{278}$ The President, after all, is accountable to the polity as a whole, not merely to some subgroup defined by narrow political interests. 279 Implicit in this reliance is the assumption that the electorate would vote the President out of office if she catered to special interest groups to the detriment of the remainder of society. ${ }^{280}$ Faced with this possibility, interest groups would agree to forfeit their own claims as long as they were assured by the election of a President who opposed special interest accommodation that the government would not adopt any other interest group's pet project. ${ }^{281}$

Unfortunately, voters in presidential elections apparently do not pursue their self-interest perfectly. Presidential politics suffers from market-type imperfections. There are information costs of determining the extent to which a candidate supports policies that benefit private interest groups ${ }^{282}$ and monitoring and policing costs of ensuring that others do not secretly support their special interest candidates. ${ }^{283}$ More significantly, voters in presidential elections in large

Crisis, 2 Stan. L. \& Pol'y Rev. 37, 37-38 (I99o); Michael Waldman, The S\&L Collapse: The Cost of a Congress for Sale, 2 STAN. L. \& Pol'y REv. 47, 48-50 (r990). Some commentators have noted that the FHLBB staff adopted accounting standards in I98I that allowed the precarious health of many savings and loans to go undetected. See Joseph A. Grundfest, Lobbying into Limbo: The Political Ecology of the Savings and Loan Crisis, 2 STAN. L. \& PoL'y Rev. 25, 29-30 (1990); Donald G. Simonson \& George H. Hempel, Running on Empty: Accounting Strategies to Clarify Capital Values, 2 STAN. L. \& PoL'y Rev. 92, 95 (I9go). One might thus conclude that capture at the career staff level contributed to the crisis, but it appears that the FHLBB changed its standards in part out of knowledge that congressional oversight committees did not want news of savings and loan failures.

${ }^{278}$ See Harold H. Bruff, Presidential Power and Administrative Rulemaking, 88 YALE L.J. 45I, 46I-62 (1979); Mashaw, supra note 153, at 95; $c f$. Pierce, supra note 200, at 522 (arguing that a President can sometimes avoid the wrath of special interests by blaming agency decisions on the agency's "independence").

279 See Strauss \& Sunstein, supra note 200 , at 190.

280 See, e.g., Mashaw, supra note 153 , at 95.

281 In essence, the threat that interest group members will vote the President out of office provides the mechanism by which these groups could police a cooperative agreement not to compete for monopoly rents and thereby avoid the prisoners' dilemma otherwise posed by the competition for such rents. See Aranson, Gellhorn \& Robinson, supra note 54, at 39-40; Farber \& Frickey, supra note 47 , at 906.

282 The economically rational voter calculations that the self-interest model assumes are complicated by the uncertainty of attributing particular effects to specific governmental policies and by the lag between the time that the government adopts a policy and the time that policy ramifications manifest themselves. A candidate from the current administration can always contend that bad times resulted from the policies of a prior administration or from unfortunate circumstances beyond the administration's control.

283 Each voter's self-interest would dictate that she secretly vote for her special interest 
measures cast their ballots in accordance with their perceptions of a candidate's general ideology. ${ }^{284}$ These perceptions in turn depend on media exposure and campaign "packaging" - precisely the benefits that the television networks and well funded political action committees can provide. ${ }^{285}$ Hence, there may be a divide between the ideology of the candidate as perceived by the public and the bargains candidates have struck to garner support from wealthy and well organized interest groups. ${ }^{286}$

Imperfections in presidential oversight of agencies also limit the ability of the White House to check agency capture. No matter how great the President's authority to dictate agency policy, the breadth and complexity of agency action exceeds any one individual's monitoring capacity. ${ }^{287}$ The President might be able effectively to monitor a few salient policies, but would have to delegate virtually all of the responsibility for monitoring others. ${ }^{288}$ Like congressional delegation to committee staffs, executive delegation to OMB and the White House staff abandons the public-interest-oriented and deliberative structures that made agency policy-setting attractive in the first place.

My rejection of congressional and presidential oversight leaves interest groups and the courts as the primary institutions to combat agency capture. Competition between interest groups can provide a powerful means of identifying and publicizing instances of capture. To ensure that agencies actually afford different interests equal respect, however, government may have to facilitate the organization of groups representing diffuse interests and to encourage political

candidate. In such a situation, the uncoordinated behavior of "economically rational" voters would result in the election of the candidate who played to the most powerful special interests.

284 See David O. Sears, Richard R. Lau, Tom R. Tyler \& Harris M. Allen, Jr., Self-Interest vs. Symbolic Politics in Policy Attitudes and Presidential Voting, 74 AM. PoL. SCI. REv. 670, $679-82$ ( 1980 ). To the extent that voters consider the national economy, they tend to look at the economy during the election year rather than to evaluate the likely effect of the candidates' programs on national economic prospects. See Ray C. Fair, The Effect of Economic Events on Votes for President, 6o Rev. Econ. \& Stat. 159, 17 (1978). But of. Michael S. LewisBeck, Economics and Elections: The Major Western Democracies 133, 155 (ig88) (contending that American voters do consider the future of the economy as well as their personal economic well-being).

285 See Stephen Hess, The Presidential Campaign 78-80 (rev, ed. 1978) (discussing the role of the networks).

${ }^{286}$ The influence of interest groups over the presidential election process may have increased recently due to the decline of the monopoly that political parties used to exercise over the nominating process. See Erwin C. Hargrove \& Michael Nelson, Presidents, Politics, AND PoLICY 162 ( 1984 ).

287 See Terry M. Moe, The Politicized Presidency, in The New Direction in American Politics 235, 243, 269 (John E. Chubb \& Paul E. Peterson eds., 1985).

288 See Hugh Hecio, A Governaent of Strangers 254 (1977); $c f$. Hugh Heclo, One Executive Branch or Many?, in BOTH ENDS of THE AvENuE 26, 35 (Anthony King ed., 1983) (stating that a president must impose a "grand simplification," or an overarching theme, if he is to effectuate his personal policy vision). 
participation by those groups. Creating divisions within the agency, each with the responsibility to serve certain groups, may also encourage deliberation. Even then, however, competition between private interest groups will not suffice to prod agencies to pursue the public interest. At best competition will replace capture that serves a single interest group with something akin to capture by a coalition of interest groups - the equilibrium ideal of pluralistic democracy that civic republicans find normatively wanting. In order to minimize capture without reinforcing pluralism, it is necessary to rely also on the judiciary to constrain agency decisionmaking.

Civic republicanism suggests three requirements that courts might impose an agency to guard against capture. Courts should require an agency to grant meaningful access to all affected groups, honestly justify its decisions by appeal to the public welfare, and act deliberatively in reaching its conclusion about which policy best serves that welfare. To implement these requirements, courts should remand agency decisions for further consideration when the agency does not actively encourage full participation by groups representing diffuse interests. Courts should also expand the "hard look" approach to judicial review of agency action to apply to all agency exercises of discretion (including statutory interpretation). In addition, the judiciary should demand that the agency explain how it conceives of the public interest, how that conception comports with the agency's authorizing statute, how the particular policy advances that conception, and why the arguments opposing that policy are less persuasive. Although this type of review provides no guarantee against policy decisions driven by agency capture, it sharply decreases the likelihood that an agency will adopt such decisions without public scrutiny and publicity. ${ }^{289}$

\section{Regulators' Pursuit of Their Own Conception of the Public Interest}

A third potential pitfall of civic republican government is that decisionmakers will implement their idiosyncratic conceptions of the

289 There is one problem related to capture for which judicial oversight might be less effective than political oversight. For traditional agencies that regulate particular industries, the existence of the agency, and hence of staff members' jobs, may depend on maintaining the viability and the structure of the industry. Agency staff members thus tend not to consider seriously alternatives that might jeopardize the industry's existence. The judiciary, however, may not have the authority to require the agency to do so, because the agency's authorizing statute usually implicitly presupposes the industry's viability and structure. See Shapiro, supra note 4, at 66. Hence, Congress itself needs to adopt legislation that alters the industry structure or restricts the agency's jurisdiction over the industry, rather than to delegate such decisions to the agency. For example, it took special legislation and the appointment of Alfred Kahn as Chairman of the Civil Aeronautics Board to deregulate the airline industry. See generally MARTHA DERTHICK \& Paul J. QUirk, The Politics of Deregulation 55 (1985) (discussing the political impact of Kahn's appointment). 
public interest rather than society's consensus about that interest. Pursuit of a personal notion of the public interest may plague congressional as well as agency decisionmaking, at least to the extent that influential members of Congress enjoy sufficient "slack" from electoral oversight. ${ }^{290}$ Nonetheless, the potential may be greater for agency members to impose their own conception of the public interest on the rest of society because they are fewer in number and feel no direct electoral constraints. ${ }^{291}$

As in the case of capture, monitoring by private interest groups may identify when an agency has gone awry, but it will not cure the problem in a suitable manner. Along with the concern that private interest group monitoring encourages agencies to seek a pluralistic equilibrium, there is the added problem that public-interest-minded decisionmakers are unlikely to be swayed by private interest group inducements.

Judicial review may help to check despotic regulators, but may not suffice on its own to avoid this pitfall. Judicial mandates of participation by all facets of society, deliberation prior to agency decisionmaking, and justification of the decision in terms of the public interest (including explanations of deviations from past conceptions) encourage regulators to think hard about their own conceptions of the public interest. Review will thus help well-meaning but misinformed regulators make better decisions. ${ }^{292}$ The danger still exists, however, that a justification of an agency decision, cloaked in the language of public interest, may in fact be based only on a regulator's idiosyncratic conception of that interest. It may be difficult for courts to determine whether a regulatory goal couched as advancing some general interest of the populace is in fact a goal shared generally by the polity or instead is a community oriented goal imposed by the agency.

The requirement that potentially affected groups participate in the deliberative process may help courts make this determination, but only to a limited extent. The record may indicate that many of the participants in the proceeding opposed a policy for sound reasons to which the agency decision did not respond. Yet the record often does not clearly reveal whether an agency policy truly comports with some shared principle of the common good; full deliberative proceedings may instead generate obfuscating arguments. A requirement of con-

290 See Kalt \& Zupan, Capture and Ideology, supra note 139, at 298; James B. Kau \& Paul H. Rubin, Self-Interest, Ideology and Logrolling in Congressional Voting, 22 J.L. \& EcoN. 365, 384 (I979); see also Arthur T. Denzau \& Michael C. Munger, Legislators and Interest Groups: How Unorganized Interests Get Represented, 80 AM. PoL. SCI. REv. 89, 90 (summarizing literature asserting that members of Congress have sufficient freedom from interest group influence to pursue their own ideological interests).

291 See Levine \& Forrence, supra note 123 , at 179-81.

${ }^{292}$ See Administrative Law Symposium: Question \& Answer with Professors Elliot, Strauss, and Sunstein, 1989 DuKE L.J. 551, 554-55. 
sistency is also not likely to constrain an agency; presumably the agency would be happy to impose its view of the public good on a consistent basis. For a reviewing court to check a regulator's imposition of her subjective conception of the public interest, the court itself would have to determine that her conception deviated from that of the polity. Giving courts this checking function thus invites judges to substitute their own conception of the public good, and judicial conceptions are likely to be more idiosyncratic than those of agency members because judges are further removed from the give-and-take of politics. ${ }^{293}$

Civic republicanism thus must also look to the politically accountable branches to constrain well-meaning but despotic agencies. In doing so, however, it must not constrain agencies in a manner that increases the power of individuals within those branches to override and control agency policymaking or else it merely invites the replacement of one despot by another. Despite this limitation, the political branches can meaningfully check runaway regulators in two ways.

First, Congress as a whole can and should directly review agency policy to ensure that it comports with the polity's conception of the public good. Congress, although not perfectly deliberative in its legislative process, is accountable to the various factions in society. Although legislative procedures favor factional influence, ${ }^{294}$ the bicameral structure of Congress, the presidential veto, and the fact that the committee system can more easily block legislation than generate it $^{295}$ all make it unlikely that a congressional override will replace an agency policy that serves the public interest with one that explicitly caters to private interests. Congress thus should play an important monitoring role, at the end of the deliberative policy-setting process, to ensure that the agency does not adopt a policy that conflicts with popular values. ${ }^{296}$ If Congress can muster the support, statutorily overruling a particular agency policy is an appropriate use of its

293 Judges' imposition of their idiosyncratic conceptions of the common good can lead to decisions that oversimplify the issues facing the agency and thereby interfere with the agency's evaluation of the complex interrelations of technology, political influence, and realities of administration. See SHAPIRo, supra note 4 , at ${ }_{5} \mathrm{I}^{\mathrm{I}}-56$. The result might then be judicially mandated "bad policy." See Jerry L. Mashaw \& David L. Harfst, The Struggle for Auto Safety 224-27 (1990); R. Shep Melnick, Regulation and the Courts: The Case of the Clean AIr ACT 366-73 (1983); Peter L. Strauss, Considering Political Alternatives to "Hard Look" Review, I989 DUKE L.J. 538, 540, 544-48.

294 See supra notes $161-167,196-199$ and accompanying text.

295 See Lawrence C. Dodd, Congress, the Constitution, and the Crisis of Legitimation, in CONGRESS RECONSIDERED, supra note 194 , at 390, $4 \mathrm{II}-13$.

296 See generally MAASS, supra note I9I, at I19-253 (discussing the methods and effectiveness of congressional oversight of executive policymaking). Congressional overrides reflect popular values that have had a chance to develop as part of a deliberative discourse at the agency level. Therefore, response to such values is more legitimate than initial congressional action, which reflects responses to preexisting values never subject to such discourse. 
legislative power. One should not, however, rely too heavily on legislative overrides. For reasons previously discussed, Congress has difficulty adopting legislation that defines a particular conception of the public interest. Hence, direct oversight is likely to provide only a weak constraint; Congress will overrule only agency policy that varies drastically from the electorate's consensus about the public interest.

Second, the President can use her appointment power to guard against regulators who are likely to entertain idiosyncratic views of the public interest. The President's ability to choose an appointee who shares her broad conception of the public interest, which presumably comports with the consensus of those who elected her, provides the most important means of keeping the bureaucracy accountable to the polity. ${ }^{297}$ Because appointments of agency members occur relatively infrequently, they attract media attention, which helps ensure that the entire electorate holds the President accountable for the quality and ideology of the appointee. ${ }^{298}$ Thus, the President's appointment power can provide another check against despotic agencies without unduly empowering the President.

I do recognize that the appointment process has not always worked to prevent runaway agencies. ${ }^{299}$ Such agencies are rare, however, which indicates that meaningful constraints already exist. Moreover, the President and the Senate have not necessarily seen appointment power as a primary check against agency despotism. ${ }^{300}$ If they were to adopt a civic republican perspective, however, their approach to

297 "By appointing individuals on the basis of loyalty, ideology, or programmatic support, [the President] can take direct action to enhance responsiveness throughout the administration, from presidential agencies like the OMB to the most remote independent boards and commissions." Terry M. Moe, The Politicized Presidency, in The New Direction in American Politics, supra note 287 , at 245 . In addition, with respect to independent commissions, the President's authority to name the chairperson gives the President significant power to implement her regulatory programs. See DerTHICK \& Quirk, supra note 289 , at 64, 86-87 (I985).

298 Paul Quirk notes that "it is relatively easy for interest groups concerned about a regulatory agency to keep informed about appointments to that agency." QUIRK, supra note 255, at 89 .

${ }^{299}$ For example, some considered the Federal Trade Commission's zealous campaign against unfair trade practices in the late 1970 s to go well beyond its political mandate. The FTC actions prompted Congress to slash the Commission's budget and to place, for three years, statutory limits on FTC authority. See Federal Trade Commission Improvements Act of 1980 , Pub. L. No. 96-252, $\S$ 18-20, 94 Stat. 374, 39I-93. President Carter's appointment of an aggressive consumer advocate, Michael Pertschuk, contributed to this controversy as well. It is unclear, however, whether the FTC really was a runaway agency, or whether, instead, Congress's action in 1980 reflected changes in the oversight committees' chairmen and the election of the more pro-business President Reagan. For a review of the perceived problem with FTC regulation and the possible causes, see Ernest Gellhorn, The Wages of Zealotry: The FTC Under Siege, 4 REG. 33, 34-40 (I980).

300 Until recently, Presidents had not appointed high level bureaucrats based on the appointees' policy views, but rather to repay political debts or on neutral merit principles. See QUIRK, supra note 255 , at 75-76; Wilson, supra note 123 , at 389-90. 
appointments would change and the appointment power would become more significant. The President would appoint agency members to implement a conception of the public good in line with that of the voters who elected her and would not treat nominations as political plums or the means of appeasing powerful interest groups. Senators would take their advise and consent role seriously to stop an appointment that appears to be a political favor. Similarly, they would oppose any nominee that they feared did not share a conception of the public interest acceptable to the polity. With these understandings in place, the appointment power provides significant protection against regulators' implementing their idiosyncratic conceptions of the public interest.

\section{Coercion by the Dominant Political Culture}

The possibility that regulators will accede to majoritarian values and conceptions of the public interest poses an even greater threat to the civic republican ideal than does the possibility of despotic agencies. Even if a system of government decisionmaking constrains regulators to adopt only policies that comported with politically supported conceptions of the common good, policies might still fail to meet the civic republican ideal. They might reflect a preconceived and inflexible "mainstream" view of the public interest that many citizens outside the dominant political culture find odious. Ensuring that regulators pursue public rather than private interests, and even doing so in a way that constrains them from imposing their own conceptions of the public interest, does not preclude tyranny by the majority. ${ }^{301}$

Majority tyranny and its concomitant coercion by the dominant culture poses a particularly vexing problem for a civic republican system of government. The system cannot rely on the political process to prevent such coercion; it is precisely because the dominant culture maintains so great an influence over the political process that the problem arises in the first place. The countermajoritarian nature of courts provides some constraints, but judges too tend to come from the mainstream of society and do not necessarily understand the interests of minorities and fringe groups. Coercion of minority groups, however, is not a problem unique to civic republicanism; it plagues all systems of majoritarian government. ${ }^{302}$ Adoption of a civic republican system, however, may have a symbolic effect that helps mitigate such coercion.

301 Madison in particular recognized the troubling nature of majority tyranny. See THE FEderalist No. Io, at 80-8I (James Madison) (Clinton Rossiter ed., I96I). Concerns about majority tyranny also appear to have motivated some of the recent calls for reviving civic republican understandings. See, e.g., Michelman, supra note II, at I494-99.

302 See, e.g., Alexis DE Tocqueville, Democracy IN AMERICA 258-62 (Phillips Bradley ed. \& Francis Bowen trans., Alfred A. Knopf I945) (1835). 
Civic republicanism puts the institutions of government on notice to watch out for coercion, even if their inherent propensity is to yield to it. Although a civic republican system has no means of ensuring that Congress, the courts, or agency officials act in good faith, it does provide guidance to government institutions, operating in good faith, to guard against inadvertent accession to majority domination. ${ }^{303}$ In particular, it calls for government encouragement and facilitation of participation by representatives of marginal interests, who can sound an alarm when government policy becomes tyrannical, ${ }^{304}$ and sensitivity to the potential for coercion, which counsels against centralized command-type regulations that leave "outsiders" no option to continue developing their unique perspectives.

In operational terms, civic republicanism counsels the government to improve the representation of marginalized groups before agencies. Congress, the President, and the courts should subsidize the organization and participation of such groups, create divisions within agencies to address the concerns of the disenfranchised, and monitor agencies to ensure that they encourage meaningful participation by representatives of all potentially affected interests. In addition, the government should take measures to encourage deliberation. Agency heads should structure agencies so that primary responsibility for policy does not rest with a single office responsive to a specific outside constituency. Agency heads should also recognize and reward cooperative staff problem-solving. Congress should require agencies to define their agendas in open proceedings and to make public the content of significant communications even if the communications occur outside of instituted proceedings. Courts should recognize that agencies lack incentives to pursue the public interest and require persuasive explanations of decisions to ensure that they do not represent mere factional deals.

Civic republicanism thus concedes that regulatory coercion of marginal interests by the dominant culture poses a difficult problem. But majoritarian tyranny poses a problem for all democratic theories. Unlike other theories, however, civic republicanism denies that the problem can be skirted simply by cordoning off certain conduct from majoritarian interference under a notion of rights. Instead, it asserts that coercion is to be avoided to the extent possible and promotes the development of a community-wide understanding of goals and prin-

303 Civic republicanism is not unique in relying on some level of good faith of public officials. Without any good faith it is doubtful that any government, founded on any political theory, could operate. This was recognized by the Federalists themselves. See The Federalist No. 56, at 346 (James Madison) (Clinton Rossiter ed., I96I).

${ }^{304}$ Cf. McCubbins \& Schwartz, supra note 73, at 173-74 (noting that agency procedures allow interest groups to obtain redress without requiring Congress to monitor agency decisions actively). 
ciples to achieve this aim. Unfortunately, the theory offers no foolproof means to reach universal consensus; in fact, perfect consensus is unachievable. This infirmity, however, does not invalidate the civic republican effort to eliminate coercion. The realistic aim of civic republican government should be to minimize coercion to the extent possible, and thereby to promote more just and democratic outcomes. If one accepts this more realistic aim, the delegation of broad policymaking authority to agencies and the application of appropriate standards of political and judicial review appear preferable to leaving such policymaking directly in the hands of Congress. Through such a process, the unelected institutions of government - agencies, endowed with a professional ethic of seeking a persuasive solution to regulatory policy, and courts, endowed with the authority to monitor agency decisions for bias against marginal interests - both get opportunities to check majoritarian tyranny.

\section{CONCLUSION}

Throughout this century, scholars have proposed various justifications for reliance on an administrative bureaucracy to set basic government policy. These justifications are incomplete and flawed. Recently proposed constitutional models based on a revival of select aspects of republican political theory, however, may provide better justification for broad administrative policymaking authority.

This thesis is controversial. Most proponents of civic republicanism have called for greater legislative responsibility over government policy-setting; others have advocated greater judicial control over political processes. Congressional procedures today, however, are unduly influenced by powerful political factions and are not capable of providing sufficient policy coordination to satisfy civic republicanism's mandate of deliberate decisionmaking. Congress may better serve the public interest by checking agency abuses once policy is made. At the other extreme, courts are too far removed from the values of the polity to satisfy civic republicanism's goal that citizens determine the common good. Administrative agencies, however, fall between the extremes of the politically over-responsive legislature and the underresponsive courts. With proper constraints on bureaucratic decisionmaking, the agencies' place in government, the professional nature of the agencies' staff, and the procedures agencies have traditionally used to set policy suggest that the administrative state holds the best promise for achieving the civic republican ideal of inclusive and deliberative lawmaking. 